\begin{tabular}{|c|c|}
\hline$\checkmark$ sciendo & 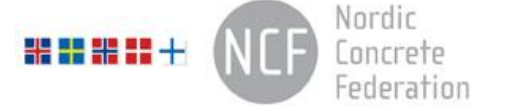 \\
\hline $\begin{array}{l}\text { (c) Article authors. This is an open access article distributed under } \\
\text { the Creative Commons Attribution-NonCommercial-NoDerivs } \\
\text { licens. (http://creaticecommons.org/licenses/by.nc-nd/3.0/). }\end{array}$ & $\begin{array}{l}\text { ISSN online } 2545-2819 \\
\text { ISSN print } \quad 0800-6377\end{array}$ \\
\hline DOI: $10.2478 /$ ncr-2021-0017 & $\begin{array}{l}\text { Received: Oct. 5, } 2021 \\
\text { Revision received: Dec. 1, } 2021 \\
\text { Accepted: Dec. 1, } 2021\end{array}$ \\
\hline
\end{tabular}

\title{
Towards Efficient Use of Cement in Ultra High Performance Concrete
}

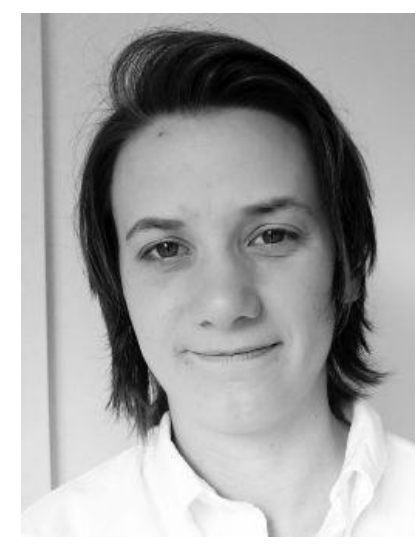

\author{
Ingrid Lande \\ M.Sc, Assistant Professor, PhD Candidate \\ Department of Engineering sciences \\ Faculty of Engineering and Science \\ University of Agder \\ Jon Lilletuns vei 9, 4879 Grimstad \\ e-mail: ingrid.lande@uia.no
}

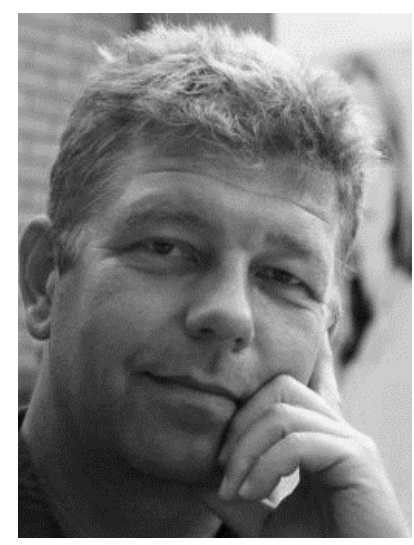

\begin{abstract}
Rein Terje Thorstensen
Professor

Department of Engineering sciences

Faculty of Engineering and Science

University of Agder

Jon Lilletuns vei 9, 4879 Grimstad

e-mail: rein.t.thorstensen@uia.no
\end{abstract}

\begin{abstract}
This paper presents an investigation on substituting the cement content with an inert material, in a typical locally produced UHPC mix. A structured literature review was performed to enrichen the discussion and to benchmark the results towards already reported investigations in the research society. Investigations on cement substitution in UHPC are frequently reported. However, usually the cement is substituted with other binding materials - often pozzolanic by-products from other industries. Reports from investigations on the use of inert materials for cement substitution in UHPC seem scarce.
\end{abstract}


An experimental program that included a total of 210 test specimens was executed. This program included evaluating several questions embedded to the problem on how to substitute cement while keeping all other variables constant.

It is concluded that up to $40 \%$ of the cement can be substituted with an inert material, without significantly changing the flexural tensile strength or compressive strength of the hardened UHPC. Two preconditions were caretaken: the particle packing was maintained by securing that the substitution material had a Particle Size Distribution (PSD) near identical to the cement and that the water balance was maintained through preconditioning of the substitution material. Suggestions are made for improving benchmarking.

Keywords: UHPC, Cement substitution, Inert material, Circular economy, Cement and $\mathrm{CO}_{2}$ efficiency indexing.

\section{INTRODUCTION}

The concrete industry is responsible for high $\mathrm{CO}_{2}$ emissions, often claimed to constitute $5-7 \%$ of the global anthropogenic $\mathrm{CO}_{2}$ emissions [1]. Concrete is by far the most applied construction material worldwide and the use is anticipated to still increase. This increase is not only due to population growth, but also due to the industrialisation of developing countries. Concrete is considered indispensable for societal development at all stages [2]. Actions need to be taken to reduce the $\mathrm{CO}_{2}$ emissions from the industry.

Mehta (2009) [3] suggested three steps towards lowering the $\mathrm{CO}_{2}$ emission from the concrete industry: (i) consume less concrete for new structures, (ii) consume less cement in concrete mixtures and (iii) consume less clinker for making cement. One strategy to reduce the consumption of concrete in new structures might be to apply stronger concrete types. This might also further reduce emissions in a lifetime perspective, due to increased durability [2]. Ultra High Performance Concrete (UHPC) has been considered a promising material for some structural purposes, especially for bridge structures [4] - both for new construction and for rehabilitation.

UHPC is defined as a cementitious composite material [5] with (i) compressive strength greater than $120 \mathrm{MPa}$, (ii) sufficient content of fibres to obtain post-cracking tensile strength and (iii) a discontinues pore structure that reduces permeability and increases durability [4]. High levels of both cement and high-strength steel fibres are consumed to obtain these properties. However, this content also contributes to high unit cost and environmental footprint. Figure 1 presents the typical composition of UHPC mixes, calculated from a number of sources reported in research [6].

According to Stengel \& Schieß1 [7] and Graybeal [8], cement and binder are typically responsible for $17-22 \%$ of the cost of UHPC, while the high-strength steel fibres are responsible for $62-73 \%$. The corresponding contributions to $\mathrm{CO}_{2}$ emissions are approximately $45 \%$ from cement and $48 \%$ from fibres, while mainly superplasticisers and silica sand are responsible for the remaining $\mathrm{CO}_{2}$ emissions (7\%) [7]. The focus of this paper is on the cement content in UHPC. In a previous paper [6], the same authors have focused on how to achieve more efficient use of fibres through hybrid configuration of macro and micro fibres in UHPC. 


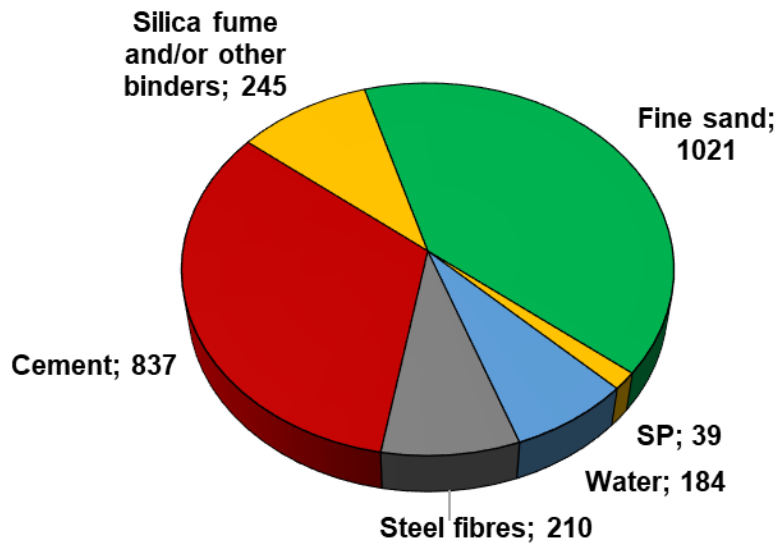

Figure 1 - Mean composition of UHPC $\mathrm{kg} / \mathrm{m}^{3}$, based on data from proprietary UHPC products and UHPC mixes reported in research papers [6].

Mehta's [3] second step for lowering the $\mathrm{CO}_{2}$ emission from the concrete industry is to consume less cement in concrete mixtures. Considering the high content of cement in UHPC, this step seems even more important. Typical for UHPC is a low water to binder ratio ( $w / b$-ratio), normally in the range $0.15-0.25$. This contributes to two of the characteristics of UHPC, increased durability and improved strength. However, the low $w / b$-ratio leads to a large portion of the cement remaining un-hydrated, thus, simply acting as filler [9]. Cement seems an unnecessary valuable filler. Replacement of cement is usually done by active mineral additions, often in form of industrial by-products. The intention of this use of Supplementary Cementitious Materials (SCMs) is often driven by a desire to increase the circular economy within the construction industry. From this starting point, several SCMs have been found to increase properties of concrete, like microsilica which has evolved to a far more expensive product than cement, only applied when special properties are needed.

In contradiction to the use of various active SCMs, in a paper reporting from a UN initiative to reduce the $\mathrm{CO}_{2}$ emission from the construction sector, Scrivener et al. [10] suggested (as one of many possible approaches) to substitute cement with inert or almost inert filler. The suggestion regards ordinary concrete, and reference is given to exactly this approach in the building of the still existing Arrowrock and Elephant Butte Dams, built more than a hundred years ago in 1912 and 1916. Considering the high amount of cement that remains un-hydrated in UHPC, this approach seems even more relevant.

This study reports from an experimental investigation on the effects on mechanical strength (compressive and flexural tensile strength) of UHPC, when cement is gradually substituted with granite powder, presumably acting as an inert filler. A systematic literature review was executed to enrichen the discussion and evaluate binder and $\mathrm{CO}_{2}$ intensity through benchmarking indexes. These efforts constitute one part of a research project on understanding the material properties and behaviour of UHPC made from local materials, with the long-term goal of facilitating the use of UHPC.

MATERIALS AND METHODS

\subsection{Literature review}

The methodology for the literature review is thoroughly reported both to secure transparency and repeatability, and because this paper constitutes a part of a $\mathrm{PhD}$ thesis, which makes 
documentation on a structured methodology vital - in contradiction to just "cherry-picking" random sources. A systematic literature search was performed to obtain relevant journal papers concerning the influence of substituting cement with other materials. The methodology was structured into four steps: (i) Formulating the research question, (ii) Identifying papers and selecting relevant papers through a screening process (Figure 2) using pre-defined inclusion and exclusion criteria (Table 1), (iii) Extracting relevant data from the papers and (iv) Analysing the findings. The research questions of this study were:

- What types of materials have been used to substitute cement in UHPC?

- How is the compressive strength influenced by a reduction in cement content?

The strategy included structured searches in the Scopus database by building three blocks of keywords of three main concepts: (i) UHPC, (ii) Cement replacement and (iii) Compressive strength. For each concept, synonyms and related terms were found to create a block of keywords. The terms/synonyms were combined with the Boolean operator "OR". The different block of keywords was searched separately and then combined with the Boolean operator "AND", ensuring that at least one term for each search block is included in the paper. The search was performed first in June 2021 and then in September 2021. The searches were applied to Title, Abstract and Keywords.

Figure 2 shows the flow chart PRISMA (Preferred Reporting Items for Systematic reviews and Meta-Analyses) [11], describing the steps from database search to the selection of relevant papers. The selection process follows four stages; (i) identification, (ii) screening, (iii) eligibility, and (iv) inclusion.

The papers identified in the search were exported to EndNote, and then to Ryyan QCRI [12] (a free web service) for screening of titles and abstracts. Inclusion and exclusion criteria (Table 1) were used to include only relevant papers in two steps. First, the title and abstract were screened, before the eligibility of the remaining papers were full-text assessed. The remaining papers in the last step were included in the analysis. Conclusively, a total of 33 papers was included. Extractions of these are presented in Section 3.

Table 1 - Exclusion and inclusion criteria.

\begin{tabular}{|c|c|}
\hline Exclusion criteria & Inclusion criteria \\
\hline Non-English language & $\begin{array}{ll}\text { - } & \text { English language. }\end{array}$ \\
\hline $\begin{array}{l}\text { - Other document types than journal } \\
\text { research papers (e.g., books, book } \\
\text { sections, reviews, conference papers). } \\
\text { - } \\
\text { - } \\
\text { - Structural memberal and numerical studies. } \\
\text { Other loadings than compression (e.g., } \\
\text { impact, blast, fatigue, shear). } \\
\text { - Investigations of early-age strength, } \\
\text { extreme conditions or curing conditions or } \\
\text { autoclave curing. }\end{array}$ & $\begin{array}{ll}\text { - Journal papers from journals with cite } \\
\text { score }>4 \text {. } \\
\text { - } \\
\text { - } \quad \text { Inverimental research paper. } \\
\text { - } \\
\text { Investigationg compressive strength. } \\
\text { a substituting material (with replacement } \\
\text { percentage }>10 \% \text { ). }\end{array}$ \\
\hline
\end{tabular}




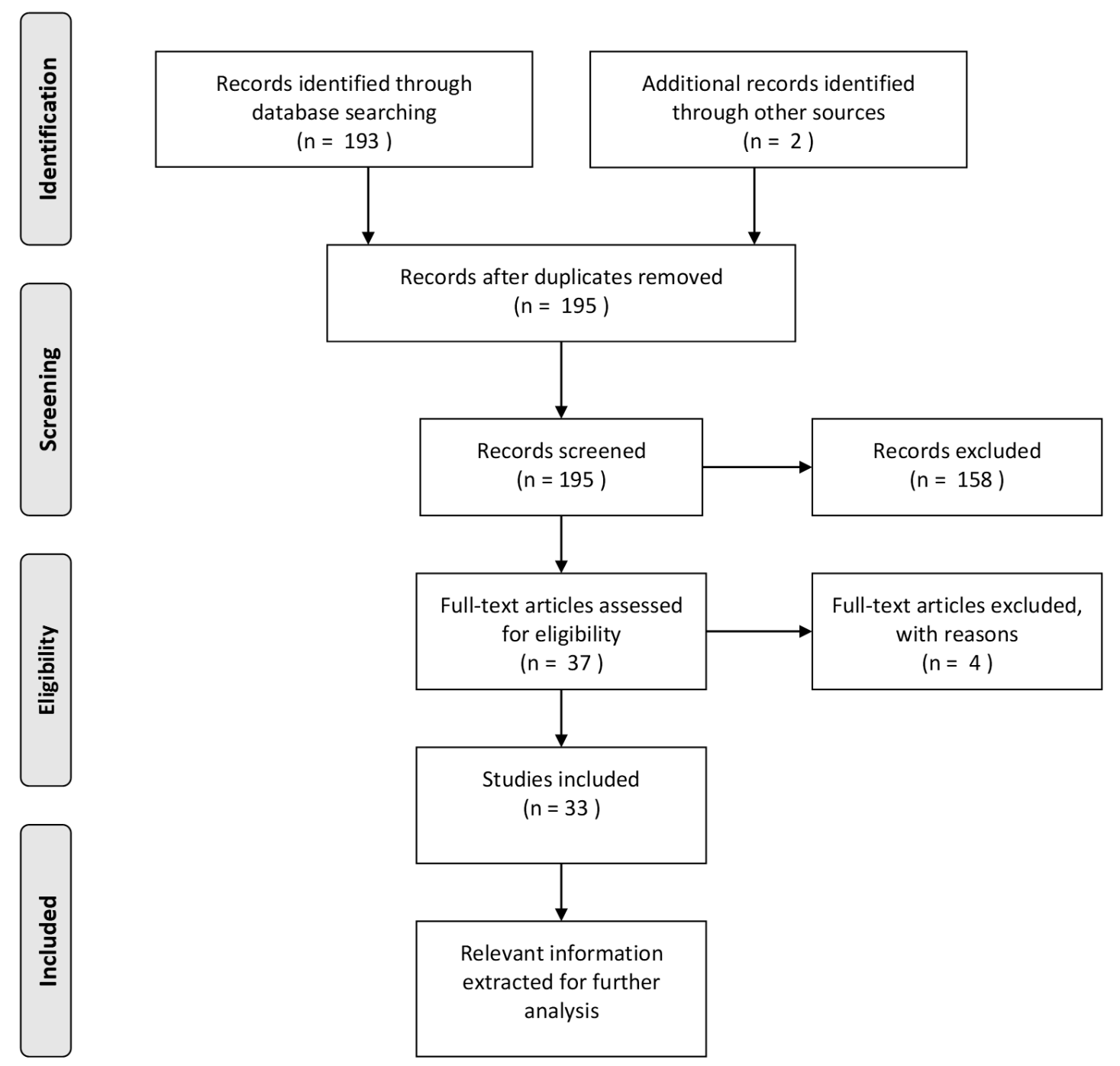

Figure 2 - The flow chart of the literature review process following the PRISMA [11].

\subsection{Experimental investigation}

\section{Materials and mix design}

The UHPC mixtures included the constituents described in Table 2 . The largest particle size $\left(D_{\max }\right)$ of the aggregate is $6 \mathrm{~mm}$, being a residue from the production of machined gravel. The fine filler material (UF) is a filter harvested powder from the production of gravel (mainly granite), used to partly replace the cement. The particle size distribution (PSD) of the cement and the UF is near identical. This can be derived from Figure 4 which reports the results of a laser diffraction investigation of the two materials. This conformity in PSDs is vital to obtain similar particle packing of the powder mix, securing that the changes in mechanical properties in the UHPC are due to changes in the cement content - not changes in particle packing of the powders. 
Table 2 - Material characteristics of the UHPC constituents.

\begin{tabular}{|c|c|c|c|}
\hline Material & Characteristics & $\begin{array}{l}\text { Density } \\
{\left[\mathrm{kg} / \mathrm{m}^{3}\right]}\end{array}$ & $D_{50}[\mu \mathrm{m}]$ \\
\hline Microsilica (MS) & Undensified microsilica & 2200 & 0.14 \\
\hline Cement & CEM I $52.5 \mathrm{~N}$ & 3100 & 14.1 \\
\hline Ultrafine filler (UF) & $\begin{array}{l}\text { Filter harvest dust from production of gravel } \\
\left(D_{\max }=0.6 \mathrm{~mm}\right)\end{array}$ & 2590 & 16.4 \\
\hline $\begin{array}{l}\text { Crushed aggregate } \\
\text { (A) }\end{array}$ & $\begin{array}{l}\text { Surplus aggregate from the production of } \\
\text { machined gravel }\left(D_{\max }=6 \mathrm{~mm}\right)\end{array}$ & 2770 & 299.2 \\
\hline Superplasticiser (SP) & Modified acrylic polymers, $18 \%$ dry content & 1060 & N/A \\
\hline Retarder $(\mathrm{R})$ & Based on sodium gluconate, $20 \%$ dry content & 1100 & N/A \\
\hline
\end{tabular}

N/A: Not applicable.

Figure 3 shows a SEM (Scanning electron microscope) image of the UF. The particle shape of the UF differs from the shape of the cement particles, potentially also influencing the particle packing. The filler has water absorption value of $10.7 \%$ and was pre-conditioned at least 24 hours before lab execution to ensure the Saturated Surface Dry (SSD) condition. This seems rather high and was consequently controlled in the university lab. The result was confirmed.
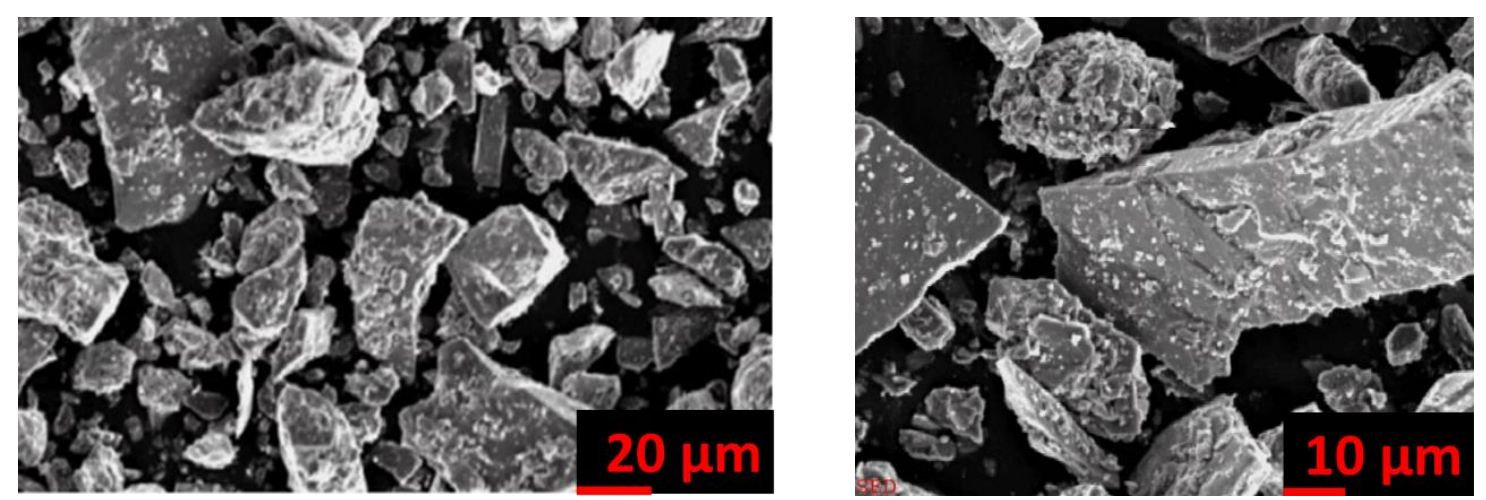

Figure 3 - Scanning electron microscope image of the inert ultrafine filler (UF) used to partly substitute cement in the UHPC mixes.

Figure $4 \mathrm{~b}$ reports the individual PSDs of cement, ultrafine filler, aggregate and microsilica. For materials with $D_{\max }<1 \mathrm{~mm}$, laser diffraction was used to obtain PSDs. A sieve analysis was used for the aggregate (A). There are disadvantages in combining measurements from indirect methods (laser diffraction) and direct methods (sieving). However, this is still applied in Figure $4 \mathrm{~b}$ due to the lack of one single method for measuring the total range in particle size, spanning 35 nanometer to $6 \mathrm{~mm}$.

The composition of the reference mix was set according to [6], to include $700-800 \mathrm{~kg} / \mathrm{m}^{3}$ of cement, and microsilica content corresponding to $25 \%$ of the mass of cement. The $w / b$-ratio was set to be either 0.25 or 0.29 in different mixes. Following numerous of the studies identified in the literature review, the modified version [13] of the Andreasen and Andersen model (AA model) for granular materials [14] was used to simulate the accumulated particle distribution of the mixes. The modified Andreasen and Andersen particle distribution curve (target curve) reads as follows (Eq. 1):

$$
C P F T=\left(\frac{D-D_{\min }}{D_{\max }-D_{\min }}\right)^{q}
$$


where CPFT is the cumulative per cent finer than size $D, D$ represents the particle size, $D_{\min }$ is the smallest particle size of the distribution and $D_{\max }$ is largest. The $q$-value is the distribution coefficient that defines the curvature of the cumulative PSD. The target curve for the relative composition of powders was defined as the densest possible particle packing according to this model. The software EMMA (Elkem Materials Mix Analyzer, version 3.5.2), which is an operationalisation of the modified AA model, was used to simulate the target curve and the PSDs of the actual powder compositions. The target curve is represented by the solid black line in Figure $4 \mathrm{~b}$, while the red and green lines represent the actual composition of the reference mix and one of the mixes with the highest cement substitution, respectively. From these curves, it seems clear that the particle packing remains stable through the substitution levels. All materials were included "as is", without any manipulation which might have been applied to obtain a better fit with the target curve.

The $q$-value is essential in the AA model, influencing the curvature of the target curve. In practice, the $q$-value is considered to rule the flowability of the mix. Following the practice of several papers identified in the literature search, a $q$-value of 0.23 was applied.

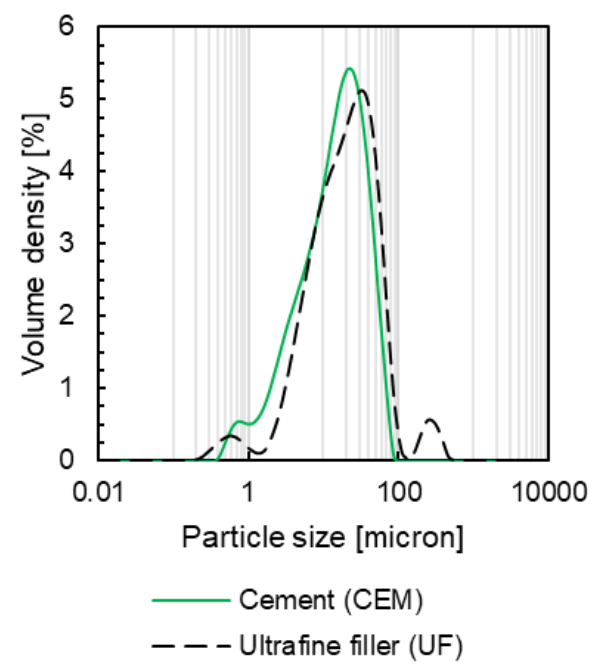

(a) Cement (CEM) compared to the inert filler $(U F)$.

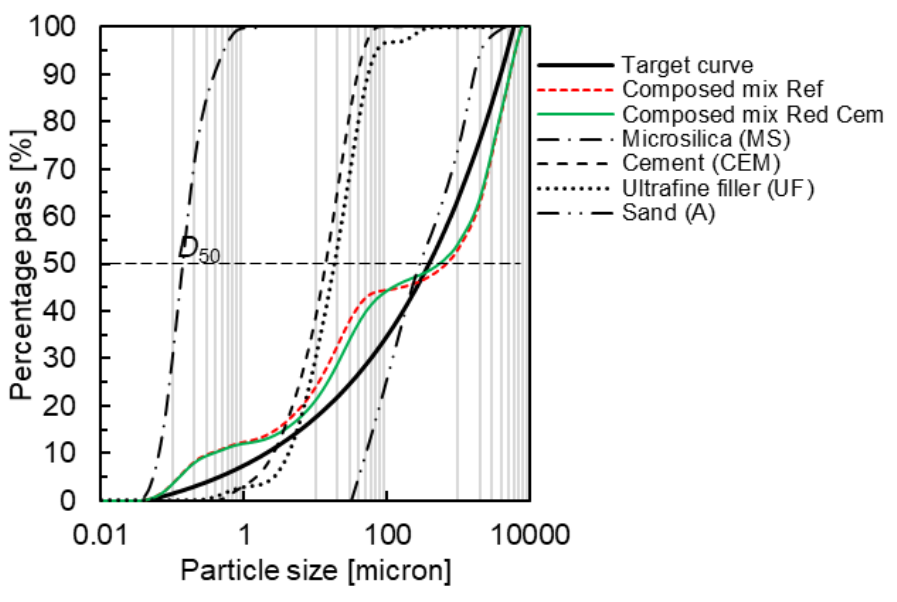

(b) PSD of all dry materials individually, the accumulated PSDs of the composed mixes and the AA model (target curve) with $q=0.23$.

\section{Figure 4 - Particle Size Distribution (PSD) of individual powders and accumulated mixes.}

Cement substitution might follow different "rules", all potentially influencing the results. Approaches through different rules were identified through the literature review. One variation that might influence the results, regards the $w / b$-ratio. When cement is substituted with an inert filler while the $w / b$-ratio is set to constant, the water content is reduced as the substitution level increases. The reduced water content might govern other properties that influence the resulting mechanical properties. As an attempt to evaluate this effect, two different $w / b$-ratios were tested. Another variation that potentially influences the results, regards the SP content. The SP is designed to act on the surface of the cement particles. Hence, the SP/C ratio should be kept constant, meaning that the SP content should be reduced correspondingly to the cement reduction. However, it is not clear whether SP also acts on the surface of other particles. Thus, it might be better to keep the SP content constant. Both approaches are tested in this investigation. 
Three groups of mixes were designed for cement substitution, following three different "rules". A total of 14 mixtures was included (Ref. in groups 2 and 3 are the same). The cement was substituted with the ultrafine filler material (UF) in steps of 10, 20, 30 and $40 \%$ by mass. The three groups and "rules" for substitution is:

1. $\quad w / b$-ratio of 0.25 and constant SP/C-ratio

2. $\quad w / b$-ratio of 0.29 and constant SP/C-ratio

3. $\quad w / b$-ratio of 0.29 and constant SP content

Table 3 shows the different mixes. The content of water includes the water content of the admixtures, excluding the water absorption in the aggregate and the filler.

Table 3 - UHPC mix proportions.

\begin{tabular}{llcccccccc}
\hline $\begin{array}{l}\text { Group } \\
\text { no. }\end{array}$ & $\begin{array}{l}\text { CEM } \\
\text { reduction }\end{array}$ & CEM $(\mathrm{C})$ & $\mathrm{UF}$ & $\mathrm{A}$ & $\mathrm{MS}$ & $\mathrm{SP}^{\mathrm{b}}$ & $\mathrm{R}$ & $\mathrm{W}(w)$ & $w / b$ \\
\hline \multirow{4}{*}{$\%$} & & $\mathrm{~kg} / \mathrm{m}^{3}$ & $\mathrm{~kg} / \mathrm{m}^{3}$ & $\mathrm{~kg} / \mathrm{m}^{3}$ & $\mathrm{~kg} / \mathrm{m}^{3}$ & $\mathrm{~kg} / \mathrm{m}^{3}$ & $\mathrm{~kg} / \mathrm{m}^{3}$ & $\mathrm{~kg} / \mathrm{m}^{3}$ & - \\
\hline & 0 (Ref.) & 756 & 0 & 1188 & 189 & 7.3 & 0.8 & 236 & 0.25 \\
1 & 10 & 690 & 77 & 1205 & 192 & 6.7 & 0.7 & 221 & 0.25 \\
& 20 & 623 & 156 & 1223 & 195 & 6.1 & 0.6 & 205 & 0.25 \\
& 30 & 553 & 237 & 1242 & 198 & 5.4 & 0.6 & 188 & 0.25 \\
& 40 & 482 & 321 & 1261 & 201 & 4.7 & 0.5 & 171 & 0.25 \\
\hline \multirow{4}{*}{2} & 0 (Ref.) & 728 & 0 & 1145 & 182 & 7.1 & 0.7 & 264 & 0.29 \\
& 10 & 667 & 74 & 1165 & 186 & 6.5 & 0.7 & 247 & 0.29 \\
& 20 & 604 & 151 & 1186 & 189 & 5.9 & 0.6 & 229 & 0.29 \\
& 30 & 538 & 231 & 1209 & 193 & 5.2 & 0.5 & 210 & 0.29 \\
& 40 & 470 & 314 & 1232 & 196 & 4.6 & 0.5 & 190 & 0.29 \\
\hline \multirow{4}{*}{3} & 0 (Ref.) & 728 & 0 & 1145 & 182 & 7.1 & 0.7 & 264 & 0.29 \\
& 10 & 667 & 74 & 1165 & 185 & 7.2 & 0.7 & 246 & 0.29 \\
& 20 & 603 & 151 & 1185 & 189 & 7.3 & 0.6 & 228 & 0.29 \\
& 30 & 537 & 231 & 1207 & 192 & 7.5 & 0.5 & 209 & 0.29 \\
& 40 & 469 & 313 & 1229 & 196 & 7.6 & 0.5 & 190 & 0.29 \\
\hline
\end{tabular}

${ }^{\mathrm{a}}$ by mass. ${ }^{\mathrm{b}}$ solid content. CEM: Cement CEM I 52.5 N. UF: Ultrafine filler. A: Surplus aggregate from

production of machined gravel. MS: Microsilica. SP: Superplasticiser. R: Retarder. W $(w)$ : Total free water,

including the water content of the admixtures, excluding the water absorption in the aggregate and the filler. $b$ :

binder $(\mathrm{CEM}+\mathrm{MS})$ content. $w / b-$ Water to binder ratio.

\section{Mixing and production}

A Hobart A200 planetary mixer (with three mixing speeds) was used. Three litres of UHPC were mixed for each batch, following the procedure in Table 4. The fresh properties were measured using a flow table with an ASTM cone (ASTM C230/C230M) following ASTM C1437. After mixing, the initial flow was immediately measured by taking two diameters perpendicular to each other. Then, the table was dropped 15 times in 45 seconds, giving two new diameters (final flow).

The UHPC was cast in cubes of $50 \mathrm{~mm}$ for compressive strength tests, or prisms of $40 \mathrm{~mm} \times 40$ $\mathrm{mm} \times 160 \mathrm{~mm}$ for both compressive strength and flexural tensile strength tests. The moulds were filled in two layers, both manually compacted. All moulds were screeded and covered with plastic sheets until demoulding about 18 hours after casting.

The $50 \mathrm{~mm}$ cube specimens were exposed to two different curing regimes. Curing at $90^{\circ} \mathrm{C}$ for 48 hours is an often seen manufacturer-recommended treatment for UHPC [15], but is difficult to apply in practical construction. The following curing regimes were applied, to evaluate the differences in effect:

a) Heat treatment in water at $90^{\circ} \mathrm{C}$ for 48 hours and tested after finished curing regime. 
b) Normal curing temperature, in water at $20^{\circ} \mathrm{C}$ for 28 days.

Table 4-Mixing procedure.

\begin{tabular}{lll}
\hline Step & Procedure & Time [sec] \\
\hline 0 & Mixing all dry constituents at low speed & 30 \\
1 & Adding water, superplasticiser, and retarder & - \\
2 & Mixing at low speed $(107 \mathrm{rpm})$ & 30 \\
3 & Pausing the mixing & 90 \\
4 & Mixing at medium speed $(198 \mathrm{rpm})$ & 120 \\
5 & Mixing at high speed $(361 \mathrm{rpm})$ & $15-30$ \\
\hline
\end{tabular}

\section{Mechanical strength tests}

Compressive testing was performed according to the ASTM C109/C109M on $50 \mathrm{~mm}$ cubes. All tests included three specimens tested in parallel, and the average value was calculated to represent the properties.

The mechanical behaviour of the UHPC mixes was also tested on prisms of $40 \mathrm{~mm} \times 40 \mathrm{~mm} \times$ $160 \mathrm{~mm}$, using the European standard NS-EN 196-1. Following this standard, both compressive strength and flexural tensile strength are achieved. Three test samples were tested in flexure and the six half-samples obtained after finishing the flexural test were tested in compression. All these test samples were heat-treated (curing regime $a$ ) at $90^{\circ} \mathrm{C}$ for 48 hours.

Small cubes were used as test specimens in accordance with most of the experimental investigations identified in the literature review. The capacity of the test machine might conflict with the strength of larger specimens with high strength (e.g., UHPC). Hence, a practical solution is to use small test specimens [16]. For normal concrete, it has been shown that smaller test specimens tend to give higher compressive strength. However, previous studies have demonstrated that the effect of size and specimen geometry (cubes and cylinders) is very small for UHPC $[16,17]$. Thus, it will not be discussed further in the present investigation.

\subsection{Cement efficiency}

The efficiency of cement replacement is evaluated based on two indexes; binder intensity (bi) representing the cost perspective, and $\mathrm{CO}_{2}$ intensity $(\mathrm{ci})$ representing the Global Warming Potential (GWP) perspective, as described by Damineli et al. (2010) [18]. The results are evaluated within the present investigation, and for comparing the results of this investigation towards the studies found in the literature review.

The binder intensity index measures the total content of binder required to give one unit of a performance, in this case, $1 \mathrm{MPa}$ of compressive strength $b i_{\mathrm{cs}}$ (Eq. 2):

$$
b i_{c S}=\frac{b}{p}
$$

where $b$ represents the total content of binder materials $\left(\mathrm{kg} / \mathrm{m}^{3}\right)$, and $p$ is the performance requirement. In this study, the performance requirement is selected to be the compressive strength (in $\mathrm{MPa}$ ) after 28 days of normal curing in $20^{\circ} \mathrm{C}$. For the values representing the experimental investigation in this study, the compressive strength was obtained from the ASTM cubes (ASTM $C 109 / C 109 M)$. The $b i_{\text {cs }}$ index is often applied to measure the economic performance in concrete [18], as the highest cost in concrete compositions is the binders. 
The $\mathrm{CO}_{2}$ emissions of the UHPC mixes are calculated using the $\mathrm{CO}_{2}$ intensity $(c i)$ index. The intention is to measure the amount of $\mathrm{CO}_{2}$ released to give one unit of performance, in this case, compressive strength $c i_{\mathrm{cs}}$ (Eq. 3) [18]:

$$
\mathrm{ci}_{C S}=\frac{c}{p}
$$

where $c$ represents the total $\mathrm{CO}_{2}\left(\mathrm{~kg} / \mathrm{m}^{3}\right)$ emissions to both produce and transport the raw materials in the concrete and $p$ is the compressive strength in MPa after 28 days of normal curing in $20^{\circ} \mathrm{C}$. The main contributor to $\mathrm{CO}_{2}$ emissions in normal concrete is cement $[18,19]$. For UHPC, the main contributors to $\mathrm{CO}_{2}$ emissions are cement (approximately $45 \%$ ) and micro steel fibres (approximately 48\%) [7]. However, only the cement content is evaluated in this investigation. The $\mathrm{CO}_{2}$ emissions from industrial by-products are considered to have no contribution to the overall $\mathrm{CO}_{2}$ emissions [19]. According to Damineli et al. (2010) [18], the $\mathrm{CO}_{2}$ emission from cement production is set to 1 tonne $\mathrm{CO}_{2}$ per tonne cement, considered to represent a world average. Norwegian production of cement (CEM I 52.5) is about 0.7 tonne $\mathrm{CO}_{2}$ equivalents per tonne cement, according to the Environmental Product Declaration (EPD) from Norcem AS. The world average value is used to facilitate international comparison. An additional value of $125.7 \mathrm{~kg}$ $\mathrm{CO}_{2}$ emission per $\mathrm{m}^{3} \mathrm{UHPC}$ is applied for the heat-treated test specimens, following Shi et al. [20].

\section{3.}

\section{RESULTS AND DISCUSSION}

\section{1}

\section{Literature review}

Table 5 shows the papers identified through the literature search, which was included in the review process. The table shows the replacement material and reduction percentage by mass (vol.\% is displayed if the reduction is given in vol.\% in the paper). The total cement content is given in the reference mix, along with the compressive strength of the reference mix $\left(\sigma_{\mathrm{cRef}}\right)$ and the compressive strength of the highest reduction percentage $\left(\sigma_{\mathrm{cMaxsub}}\right)$.

Table 5 - Overview of the included papers on cement substitution in UHPC, with extracted data.

\begin{tabular}{|c|c|c|c|c|c|}
\hline Authors (year) & Replacement material & $\begin{array}{l}\text { CEM content } \\
\text { in Ref. }[\mathrm{kg}]\end{array}$ & $\begin{array}{l}\% \text { CEM } \\
\text { replacement }\end{array}$ & $\begin{array}{l}\sigma_{\text {cRef }} \\
{[\mathrm{MPa}]}\end{array}$ & $\sigma_{\text {cMaxsub } \%}$ \\
\hline $\begin{array}{l}\text { Abdulkareem et al. } \\
(2021)[21]\end{array}$ & GGBS & 977.0 & $\begin{array}{l}30,50 \text { and } 80 \\
\text { vol. } \%\end{array}$ & $153.1^{\mathrm{a}}$ & $111.8^{\mathrm{a}}$ \\
\hline $\begin{array}{l}\text { Aghdasi \& Ostertag } \\
\text { (2018) [22] }\end{array}$ & FA and GGBS & N/A & $\begin{array}{l}50(25 \% \text { FA } \\
\text { and } 25 \% \\
\text { GGBS })\end{array}$ & 144.8 & 133.8 \\
\hline $\begin{array}{l}\text { Ahmed et al. (2021 } \\
\text { a) [23] }\end{array}$ & FA & 935.0 & $20,40,60,70$ & 198.9 & 106.9 \\
\hline $\begin{array}{l}\text { Ahmed et al. (2021 } \\
\text { b) [24] }\end{array}$ & GGBS & N/A & $15,30,45,60$ & $180^{\mathrm{b}}$ & 151.0 \\
\hline $\begin{array}{l}\text { Aldahdooh et al. } \\
\text { (2013) [25] }\end{array}$ & Palm oil fuel ash & 720.5 & 25,50 vol. $\%$ & 181.4 & 156.7 \\
\hline $\begin{array}{l}\text { Alsalman et al. } \\
(2020)[26]\end{array}$ & FA & $1104.9^{\mathrm{d}}$ & $30,40,50$ & $150.2^{\mathrm{c}}$ & $111.1^{\mathrm{c}}$ \\
\hline $\begin{array}{l}\text { Ganesh \& Murthy } \\
\text { (2019) [27] }\end{array}$ & GGBS & 960.0 & $20,40,60,80$ & 115.7 & 101.2 \\
\hline $\begin{array}{l}\text { Hou et al. (2021) } \\
{[28]}\end{array}$ & Red mud & 750.0 & $20,40,60$ & 159.7 & 81.3 \\
\hline
\end{tabular}




\begin{tabular}{|c|c|c|c|c|c|}
\hline Authors (year) & Replacement material & $\begin{array}{l}\text { CEM content } \\
\text { in Ref. }[\mathrm{kg}]\end{array}$ & $\begin{array}{l}\% \text { CEM } \\
\text { replacement }\end{array}$ & $\begin{array}{l}\sigma_{\text {cRef }} \\
{[\mathrm{MPa}]}\end{array}$ & $\sigma_{\mathrm{cMaxsub} \%}$ \\
\hline $\begin{array}{l}\text { Huang et al. (2017) } \\
\text { [29] }\end{array}$ & LP & 1251.2 & $\begin{array}{l}34,54,74 \\
\text { vol. } \%\end{array}$ & $145^{b}$ & $112.5^{b}$ \\
\hline Jing et al. (2021) & FA (cenosphere) & 965.0 & $\begin{array}{l}10,20,30,40 \\
\text { vol. } \%\end{array}$ & $107^{\mathrm{a}, \mathrm{b}}$ & $96^{\mathrm{a}, \mathrm{b}}$ \\
\hline Li et al. (2020) [31] & LP & 1071.8 & $\begin{array}{l}20,40,60,80 \\
\text { vol. } \%\end{array}$ & 152.9 & 75.5 \\
\hline Li et al. (2019) [32] & $\begin{array}{l}\text { Ternary/quaternary } \\
\text { blends of cement or } \\
\text { slag cement with LP } \\
\text { and MS }\end{array}$ & N/A & $10,20,30(\mathrm{LP})$ & $153^{\mathrm{b}}$ & $150^{\mathrm{b}}$ \\
\hline Li et al. (2021) [33] & Waste basalt powder & 856.5 & $15,30,45$ & 155 & 115 \\
\hline $\begin{array}{l}\text { Ling et al. (2021) } \\
\text { [34] }\end{array}$ & Iron ore tailing & 750.0 & $10,20,30$ & $121^{\mathrm{b}}$ & $119^{\mathrm{b}}$ \\
\hline $\begin{array}{l}\text { Liu et al. (2021 a) } \\
\text { [35] }\end{array}$ & $\begin{array}{l}\text { Carbonated or non- } \\
\text { carbonated converter } \\
\text { steel slag powder }\end{array}$ & 925.0 & $\begin{array}{l}15,30,45,60 \\
\text { vol. } \%\end{array}$ & $158^{b}$ & $120,107^{\mathrm{b}}$ \\
\hline $\begin{array}{l}\text { Liu et al. (2021 b) } \\
\text { [36] }\end{array}$ & $\begin{array}{l}\text { LP, quartz powder and } \\
\text { wollastonite powder }\end{array}$ & 810.0 & 20 & 105 & 119 \\
\hline $\begin{array}{l}\text { Mao et al. (2019) } \\
\text { [37] }\end{array}$ & Recycled powder & 1000.0 & $10,20,30,40$ & $129^{\mathrm{b}}$ & $115^{\mathrm{b}}$ \\
\hline $\begin{array}{l}\text { Meng et al. (2017) } \\
\text { [38] }\end{array}$ & GGBS or FA & 712.0 & $\begin{array}{l}30,40,50,60 \\
\text { vol. } \%\end{array}$ & 135 & 120,124 \\
\hline $\begin{array}{l}\text { Qian et al (2020) } \\
\text { [39] }\end{array}$ & $\begin{array}{l}\text { Dehydrated cement } \\
\text { paste from recycled } \\
\text { construction waste } \\
\text { cementitious material }\end{array}$ & 400.0 & $\begin{array}{l}12.5,25,37.5 \\
50\end{array}$ & $107^{\mathrm{b}}$ & $87^{\mathrm{b}}$ \\
\hline $\begin{array}{l}\text { Randl et al. (2014) } \\
\text { [40] }\end{array}$ & $\begin{array}{l}\text { FA or two types } \\
\text { GGBS }\end{array}$ & 729.0 & $45 \%$ & 166.1 & $\begin{array}{l}124.7- \\
163.5\end{array}$ \\
\hline $\begin{array}{l}\text { Shi et al. (2019) } \\
{[20]}\end{array}$ & GGBS & 634.0 & $\begin{array}{l}17,34,59,67 \\
75,84,92^{\mathrm{d}}\end{array}$ & $140^{b}$ & $44^{\mathrm{b}}$ \\
\hline $\begin{array}{l}\text { Soliman \& Tagnit- } \\
\text { Hamou (2016) [41] }\end{array}$ & Glass powder & 807.0 & $\begin{array}{l}10,20,30,40 \\
50\end{array}$ & $170^{b}$ & $145^{\mathrm{b}}$ \\
\hline $\begin{array}{l}\text { Tahwia et al. } \\
\text { (2021) [42] }\end{array}$ & FA or GGBS & 1000.0 & 30,50 & 163.4 & $\begin{array}{l}160.9 \\
136.8\end{array}$ \\
\hline $\begin{array}{l}\text { Wang et al. (2021) } \\
\text { [43] }\end{array}$ & $\begin{array}{l}\text { Expanded perlite } \\
\text { powder }\end{array}$ & 880.0 & $20,40,60$ & 180.4 & 153.1 \\
\hline $\begin{array}{l}\text { Wang et al. (2018) } \\
\text { [44] }\end{array}$ & Lead-zinc tailings & 750.0 & $10,20,30,40$ & $180^{b}$ & $140^{\mathrm{b}}$ \\
\hline $\begin{array}{l}\text { Wu et al. (2017) } \\
\text { [45] }\end{array}$ & FA or GGBS & 792.0 & $20,40,60$ & 149.8 & $\begin{array}{l}138.2,144 \\
\mathrm{~b}\end{array}$ \\
\hline $\begin{array}{l}\text { Xu et al. (2021) } \\
\text { [46] }\end{array}$ & $\begin{array}{l}\text { Ceramic tile waste } \\
\text { powder }\end{array}$ & N/A & $\begin{array}{l}15,25,35,45, \\
55\end{array}$ & $127^{\mathrm{b}}$ & $117^{\mathrm{b}}$ \\
\hline $\begin{array}{l}\text { Yang et al. (2020) } \\
\text { [47] }\end{array}$ & $\begin{array}{l}\text { Quarry stone powders } \\
\text { (basalt and LP) }\end{array}$ & 720.0 & 22,44 & 122.4 & $116^{\mathrm{b}}, 118^{\mathrm{b}}$ \\
\hline $\begin{array}{l}\text { Yu et al. (2017) } \\
{[48]}\end{array}$ & FA, GGBS or LP & 883.9 & 30 & $114^{\mathrm{b}}$ & $102-112^{b}$ \\
\hline $\begin{array}{l}\text { Yu et al. (2015) } \\
\text { [49] }\end{array}$ & FA, GGBS or LP & $883.9-896.3$ & 30 & $113^{b}$ & $97-110^{b}$ \\
\hline $\begin{array}{l}\text { Zhang \& Zhao } \\
\text { (2017) [50] }\end{array}$ & $\begin{array}{l}\text { LP, rich husk ash or } \\
\text { kaolin }\end{array}$ & 875.0 & $30,35,45^{\mathrm{d}}$ & $114^{\mathrm{b}}$ & $87-114^{b}$ \\
\hline Zhang et al. (2019) & Steel slag & 620.2 & $10,20,30$ & $181^{\mathrm{b}}$ & $170^{\mathrm{b}}$ \\
\hline
\end{tabular}




\begin{tabular}{llllll}
\hline Authors (year) & Replacement material & $\begin{array}{l}\text { CEM content } \\
\text { in Ref. [kg] }\end{array}$ & $\begin{array}{l}\% \text { CEM } \\
\text { replacement }\end{array}$ & $\begin{array}{l}\sigma_{\text {cRef }} \\
{[\mathrm{MPa}]}\end{array}$ & $\sigma_{\mathrm{cMaxsub} \%}$ \\
\hline $\begin{array}{l}\text { Zhu et al. (2016) } \\
\text { [52] }\end{array}$ & $\begin{array}{l}\text { Powder from waste of } \\
\text { clay bricks }\end{array}$ & N/A & $9,18,27$ & $80^{\mathrm{b}}$ & $75^{\mathrm{b}}$ \\
\hline
\end{tabular}

$\sigma_{\mathrm{cRef}}$ Average compressive strength for reference mix. $\sigma_{\mathrm{cMaxsub} \%}$ : Average compressive strength for mix with highest substitution percentage of cement. ${ }^{\text {a }} 90$ day strength. ${ }^{b}$ Read off figure. ${ }^{c}$ heat curing $90^{\circ} \mathrm{C}$, tested after 28 days. ${ }^{\mathrm{d}}$ calculated from info given. CEM: Cement. MS: Microsilica. LP: Limestone powder. GGBS: Ground granulated blast-furnace slag. FA: Fly ash. N/A: Not Applicable/available.

A variety of materials are used for cement substitution, often reflecting what is available at each location. Most materials are considered to have binding properties - some to be near inert. All are described as by-products from other industries, thus, accommodating a circular economy. Microsilica is normally not considered an SCM in this aspect, as it is one of the essential constituents in UHPC. The average microsilica content identified through these papers is ca. 140 $\mathrm{kg} / \mathrm{m}^{3}$, in most cases kept constant through all replacement levels. The replacement level of cement is investigated from 10 to above $90 \%$. The results of these studies are discussed in Sections 3.2 and 3.3 towards the results of the experimental investigation.

\section{2}

\section{Experimental investigation}

Flow

Ideally, in experimental investigations only one parameter should be varied at the same time, evaluating the impact of variations in just this parameter. However, variations in one parameter often induce changes in other aspects. In this case, reductions in cement content raise questions on how the two parameters $w / b$-ratio and SP content is kept constant - i.e., avoiding that also these parameters influence the results. To accommodate this intention, three groups of cement replacement investigations were designed; keeping $w / b$-ratio constant through two different levels $(w / b=0.25$ in Group 1 and $w / b=0.29$ in Group 2), and keeping SP constant through two different measurements (SP/C = constant in Group 2 and SP content constant in Group 3). All variations are expected to influence fresh consistency, thus, possibly also influencing the mechanical properties in hardened state. A decrease in workability might negatively influence the placing of the UHPC mortar in the moulds, possibly leading to more air voids and hence reduced strength in the hardened product.

Figure 5 a shows the initial and final flow (according to the ASTM C1437) at all substitution levels and two different $w / b$-ratios (Group 1 and 2).

The reference mixes show higher flow for Group 2 (exceeding the size of the flow table) than Group 1, having the higher $w / b$-ratio. However, already at $10 \%$ substitution level, this difference is nearly ruled out. For higher substitution levels, the flow is still stepwise reduced, but in small scale. The deviation from linear development might represent statistical variations related to the method. A corresponding loss of flow at increasing levels of cement substitution can be found in the literature, e.g. as described in [37]. Still, a discussion on causes and effects might be enlightening. 


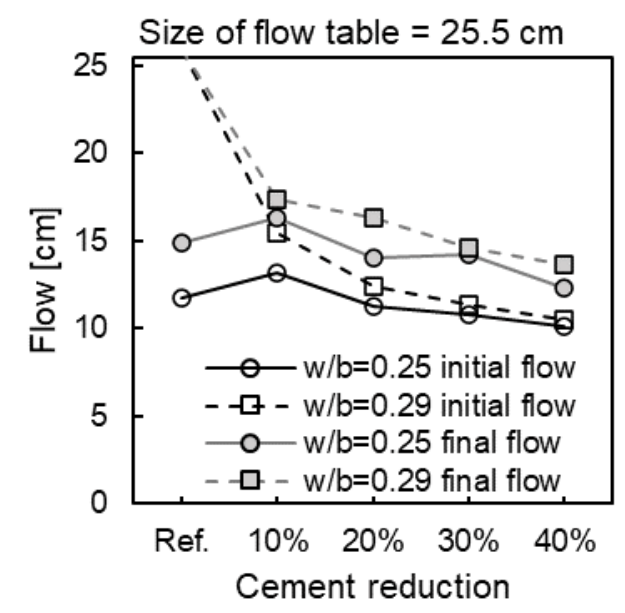

(a) Variation between groups with different w/b-ratio (Groups 1 and 2).

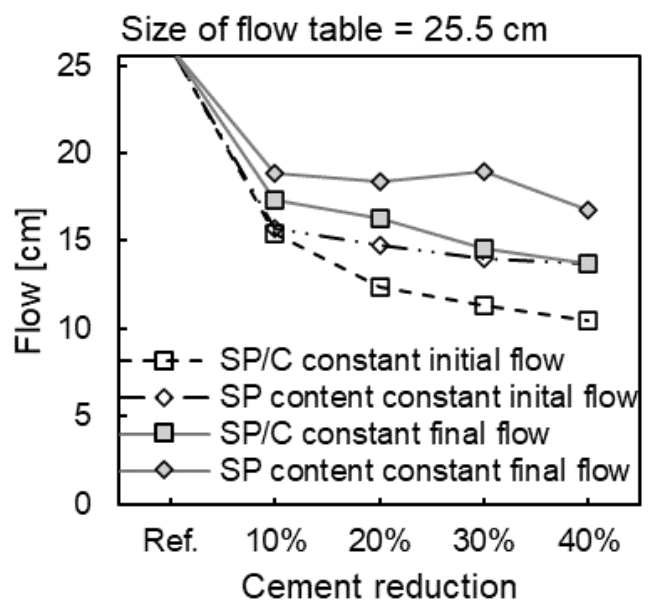

(b) Variation between groups with different $S P$ rules; $S P / C$ constant and $S P$ content constant (Groups 2 and 3).

\section{Figure 5 - Initial and final flow.}

The PSD of the cement and filler is near identical (Figure 4). Thus, the substitution is probably not influencing the flow due to differences in PSD. However, the flow reduction might have at least two other causes. One is possible water absorption in the filler. The absorption potential of the filler is $10.7 \%$, according to the product declaration sheet. To avoid problems with water absorption, the filler was pre-conditioned with $10.7 \%$ water and matured for at least 24 hours. The material might still not be Saturated Surface Dry (SSD) as intended, but at least the effect of water absorption is tentatively eliminated. Another explanation for the loss of flow is the "edgy" shape of the filler particles demonstrated in Figure 3. This shape increases the internal friction in the matrix and remains the most probable explanation for the loss of flow. However, the difference in flow between the two groups for all substitution levels (10-40\%) remains small, near the scale of statistical variations caused by the measurement method. Hence, the between-group variations seem not to have the potential for explaining possible differences in mechanical properties between specimens from Groups 1 and 2.

Figure $5 \mathrm{~b}$ shows the initial and final flow at all substitution levels with two different rules for keeping SP constant. The flow is far more influenced by the introduction of the filler ( 0 to $10 \%$ cement substitution), than by successive substitutions at higher levels (10-40\%). There is a weak linear decrease in flow as the substitution level increases. However, the variations are scaled near the statistical variations of the measurement method. Overall, the differences remain small, probably not sufficient for explaining significant differences in mechanical properties of the hardened UHPC.

\section{Flexural tensile strength in hardened state}

Figure 6 shows the flexural tensile strength of the $40 \mathrm{~mm} \times 40 \mathrm{~mm} \times 160 \mathrm{~mm}$ prisms at increasing levels of cement substitution. In Figure 6 a, the development of flexural tensile strength at increasing substitution levels is compared for two different $w / b$-ratios (Group 1 vs Group 2). The development of flexural tensile strength seems not to be influenced by variations in the $w / b$-ratio at any substitution level. The graphs are nearly overlapping, and the small variations are within the statistical uncertainty of the measurement method. 
Figure $6 \mathrm{~b}$, where the development in flexural tensile strength is compared for two different regimes on SP content (Group 2 vs Group 3), reveals some larger deviations. However, the statistical variations are in the same range, and the fluctuations of the lower curve might rather be caused by statistical uncertainty than variations in actual physical properties. Thus, it is concluded that nor the two different rules for keeping SP constant causes differences in flow that might explain substantial variations in mechanical properties of UHPC in hardened state.

It is mentioned that in practice UHPC always contain large amounts of micro fibres. The fibres are the main contributor to the typical high tensile strength of UHPC. Though neither differences in $w / b$-ratio nor in SP content was found to cause differences in flexural tensile strength of the mortar in this investigation, both might cause differences in how fibres contribute to tensile strength when these are included in the UHPC.

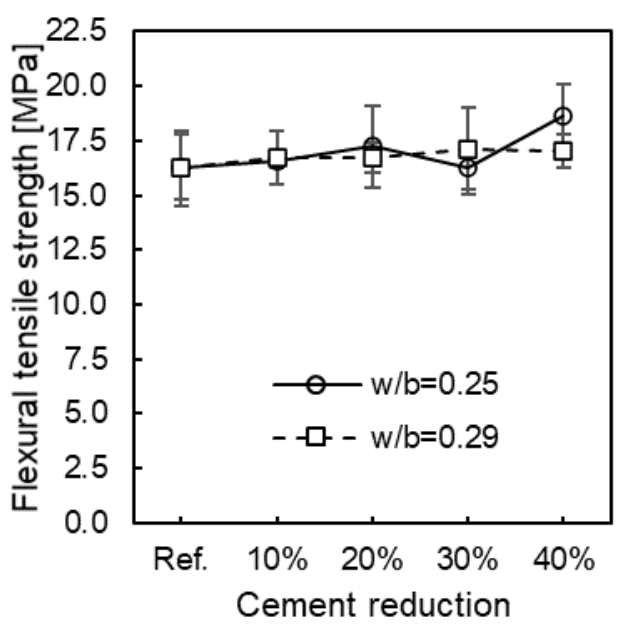

(a) Variation between groups with different w/b-ratio (Groups 1 and 2)

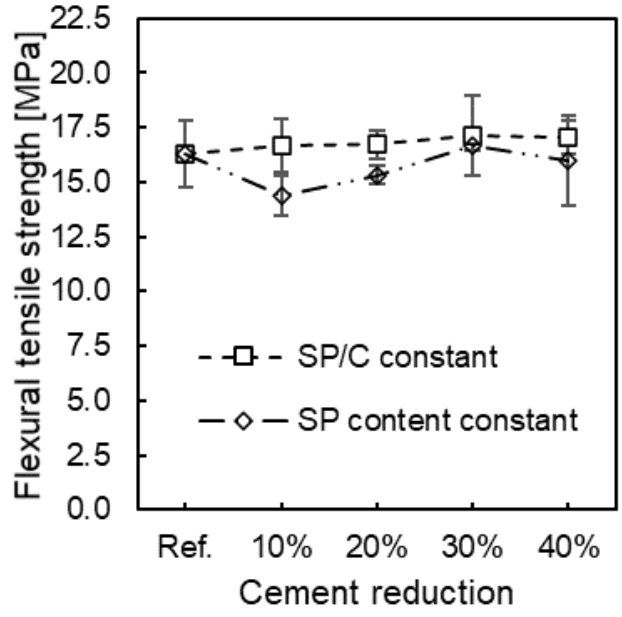

(b) Variation between groups with different $S P$ rules; $S P / C$ constant and SP content constant (Groups 2 and 3).

Figure 6 - Flexural tensile strength (NS-EN 196-1) for all replacement percentages after heat treatment curing. Error bars show the SD values.

\section{Compressive strength in hardened state}

The compressive strength of all mixes in this investigation is in the lower range of what is normally defined as UHPC. Though, when cured at elevated temperature, the results are within the definition stated by [4]. The limited compressive strength was suspected to be influenced by the newly acquired aggregate being weak. Fracture through the aggregate particles post-testing was frequently observed, strengthening this theory. To evaluate this potential explanation, a test using natural aggregates with corresponding PSD curves to the original aggregates was tested in the same UHPC composition. The result from this test was a $16 \%$ increase in average compressive strength. This was considered a satisfactory indication of the potential in the UHPC composition.

Figure 7 shows the development of compressive strength for specimens cured at high temperature (heat treatment) and tested according to NS-EN 196-1 at all substitution levels, compared for variations in $w / b$-ratio and SP regimes. Each data point is the average of 6 specimens tested in parallel. The reference mixes had a mean compressive strength of 122.9 to $131.8 \mathrm{MPa}$. The compressive strength shows only small variations within the parallel tests for all cement substitution levels up to $40 \%$, all considered to be within the range of the statistical variations of 
the measuring method. Neither variations in $w / b$-ratio (Figure 7 a) nor in SP regime (Figure 7 b) influence these compressive strength results.

Normally in concrete technology, an increase in water content is expected to lead to an increase in porosity and hence reduced compressive strength. According to Figure 7 a, the reference mix with the lowest $w / b$-ratio (Group 1) has slightly higher compressive strength than the reference mix with a higher $w / b$-ratio (Group 2). The difference is small, and already at the first introduction of the filler (substitution level 10\%), this difference is reduced. In cases where low $w / b$-ratios is limiting the amount of water available for cement hydration, it has formerly been shown that small increases in $w / b$-ratios have little influence on the strength of UHPC [49].

It is known that the pozzolanic effect that creates binder from microsilica increases at elevated temperature curing. The high amount of microsilica normally used in UHPC (in this case 25 mass$\%$ of the cement in the reference), might also be part of the explanation why a change in $w / b$-ratio does not influence the compressive strength. If the amount of calcium hydroxide released from the (limited) cement hydration throughout all substitution levels remains sufficient for all the microsilica to react pozzolanicly, the relative influence of the cement hydration is reduced compared to what happens in ordinary concrete with low microsilica level and without the benefit of elevated temperature curing. This explanation might be strengthened if specimens cured at lower temperature reveals different results from variations in $w / b$-ratio.

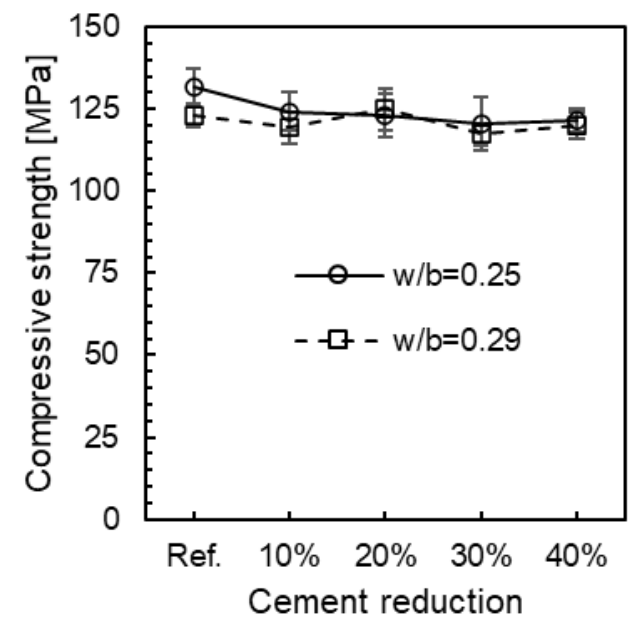

(a) Variation between groups with different w/b-ratio (Groups 1 and 2)

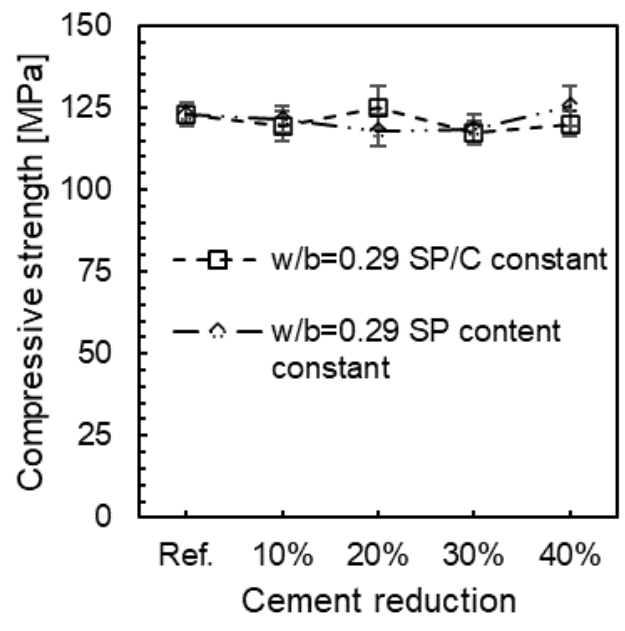

(b) Variation between groups with different $S P$ rules; $S P / C$ constant and $S P$ content constant (Groups 2 and 3)

Figure 7 - Compressive strength (NS-EN 196-1) for all replacement percentages after heat treatment curing. Error bars show the $S D$ values.

The effect of different curing regimes on compressive strength was investigated. The results are presented in Figure 8. For all Groups illustrated in Figure 8 (a through c), the compressive strength achieved at $20^{\circ} \mathrm{C}$ is around $15 \%$ lower than those at $90^{\circ} \mathrm{C}$ except for one single data point (Figure $8 \mathrm{~b}$ at $30 \%$ substitution level). This lack of correspondence in one point could be an outlier. The general increase in compressive strength achieved at elevated temperature is anticipated to be caused by the increased pozzolanic action at high-temperature curing, described above. However, since the relative differences between the two curves in each of the figure remains close to 
constant, it seems not relevant like indicated above, to relate the lack of reduction in compressive strength at high substitution levels to the increased pozzolanic action at elevated temperature.

A discrepancy between the results illustrated in Figures 8 a and b versus those in Figure $7 \mathrm{a}$, is that the compressive strength results seem to be influenced by the lower $w / b$-ratio in Figure 8 while not in Figure 7. These are the results from two different tests; Figure 7 is presenting the results from tests according to NS-EN 196-1, while Figure 8 is according to ASTM C109/C109M. One clear difference is the geometry of the test specimens. ASTM uses $50 \mathrm{~mm}$ cubes, while $N S$ $E N$ applies compressive load from square $40 \mathrm{~mm}$ surfaces towards approximately one half of a $40 \mathrm{~mm} \times 40 \mathrm{~mm} \times 160 \mathrm{~mm}$ prism. However, there might also be other differences between the two regimes. A paper, where inconsistencies between results from the standards for measuring the pozzolanic effect of cement substitution found in ASTM and EN is investigated [53], reveals that multiple factors e.g. the type of SP and the fineness of cement influence the test results in these two standards differently.
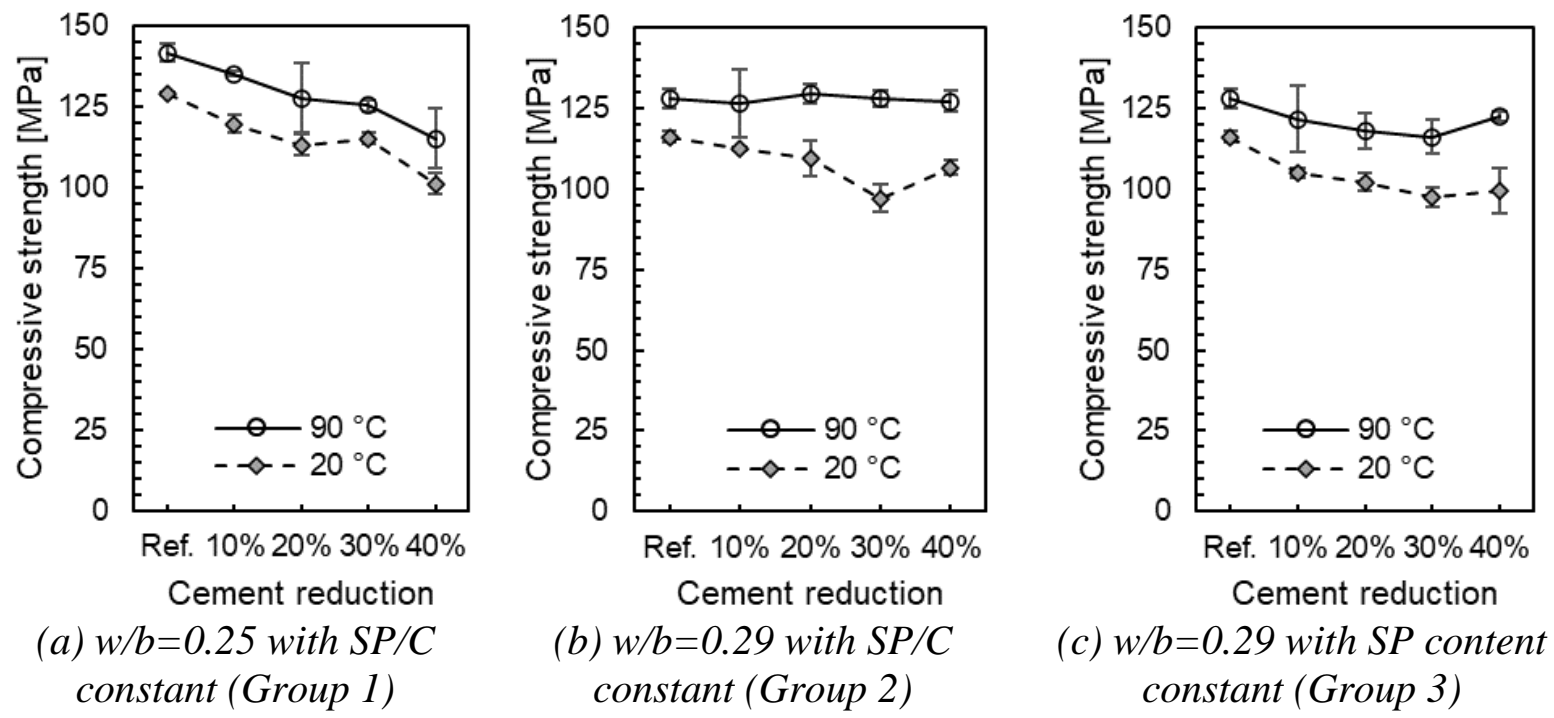

Figure 8-Compressive strength (ASTM C109/C109M) following different curing regimes (heat treatment at $90^{\circ} \mathrm{C}$ for 48 hours or normal curing at $20^{\circ} \mathrm{C}$ for 28 days), for all replacement levels. Error bars show the SD values.

To evaluate whether there are systematic differences between the two testing regimes (ASTM vs $N S-E N)$ in this investigation results from the compressive strength tests according to the two standards are compared in Figure 9. Though there are some differences, these seem to be within the range of the statistical variations of the methods. Hence, there does not seem to be any systematic differences between the results obtained from testing according to ASTM compared to those from $N S-E N$. The discrepancy discussed above between the results shown in Figures 8 a and $\mathrm{b}$ from those in Figure 7 a, remains unsolved.

However, after a thorough discussion on substituting up to $40 \%$ of the cement in UHPC by an inert filler having PSD near identical to that of the substituted cement, the major conclusion is that the effect on strength is negligible. An explanation might be that the amount of cement that hydrates remain constant through all substitution levels. The cement particles that remain unhydrated might be substituted with inert particles without compromising the strength of the UHPC. 


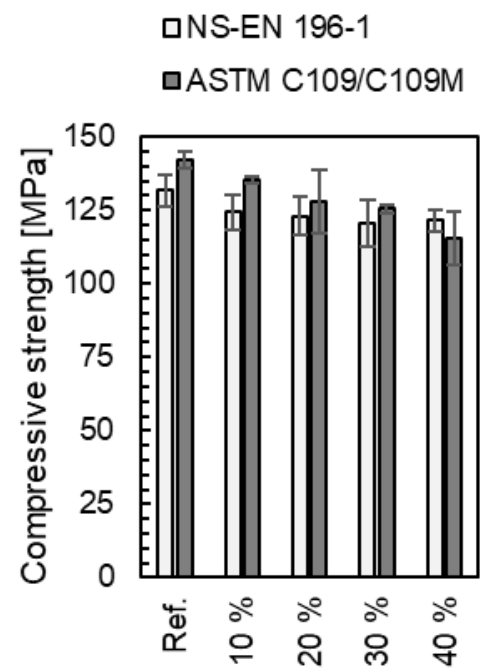

(a) $w / b=0.25$ with $S P / C$ constant (Group 1)
口NS-EN 196-1

口ASTM C109/C109M

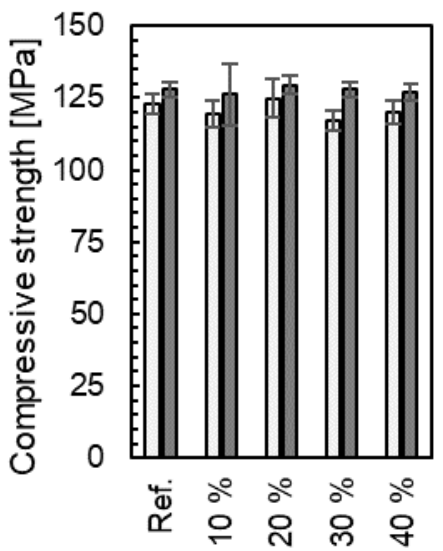

(b) $w / b=0.29$ with $S P / C$ constant (Group 2)
口NS-EN 196-1

口ASTM C109/C109M

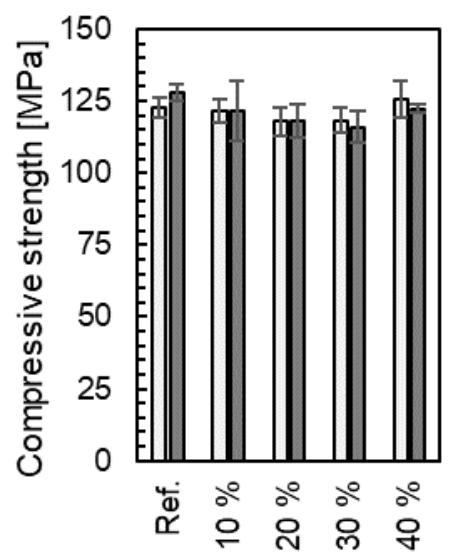

(c) $w / b=0.29$ with SP content constant (Group 3)

Figure 9 - Compressive strength following ASTM C109/C109M and NS-EN 196-1 for heattreated test specimens.

\section{Comparison with results from the literature review}

Figure 10 shows the compressive strength versus the total cement content (Figure 10 a) and total binder content (Figure $10 \mathrm{~b}$ ) of the results from this study compared to results extracted from the literature review. All investigations shown in Figure 10, except two, use small cube specimens.

The compressive strength in this study is lower than the average compressive strength for the different UHPC mixes obtained from the literature review (after 28 days standard curing at $20^{\circ} \mathrm{C}$ ). This is partly explained above with low-quality aggregate. And it is not central to the focus of this paper. However, what is interesting is the inclination of a linear regression line between the data points, shown for some of the investigations in Figure 10 a. This line represents the continuous effect on compressive strength, caused by the cement substitution. The inclination represents the average strength loss per unit of cement, during the stepwise substitution. Comparing the inclination of these lines between investigations reveals that the results on compressive strength during cement substitution found in the present investigation corresponds closely to the results from most of the papers identified in the literature review. The low inclinations of some of the lines (including the present investigation) show only limited strength loss from cement reduction of about $40 \%$ starting from an average level of around $750 \mathrm{~kg}$ cement per $\mathrm{m}^{3}$. It is, however, also worth noticing that there seems to be a threshold under which the cement content should not be reduced. This is visible from Figure 10 a, where the results from Shi et al. (2019) [20] seem to have a breaking point around $250 \mathrm{~kg} / \mathrm{m}^{3}$.

What differs the present investigation from most other investigations identified in the literature review, is the properties of the material used for cement substitution. This becomes observable from Figure $10 \mathrm{~b}$, showing compression strength versus total binder content. The inclination of the linear regression lines (not depicted) from many investigations becomes vertical. The reason is that most investigations use materials with binding properties for cement substitution. Thus, the binder content is not reduced. The investigation presented in this paper utilises an inert (waste) material for cement substitution, yet achieves corresponding strength results as the others. Only a few other investigations have tried this approach. 


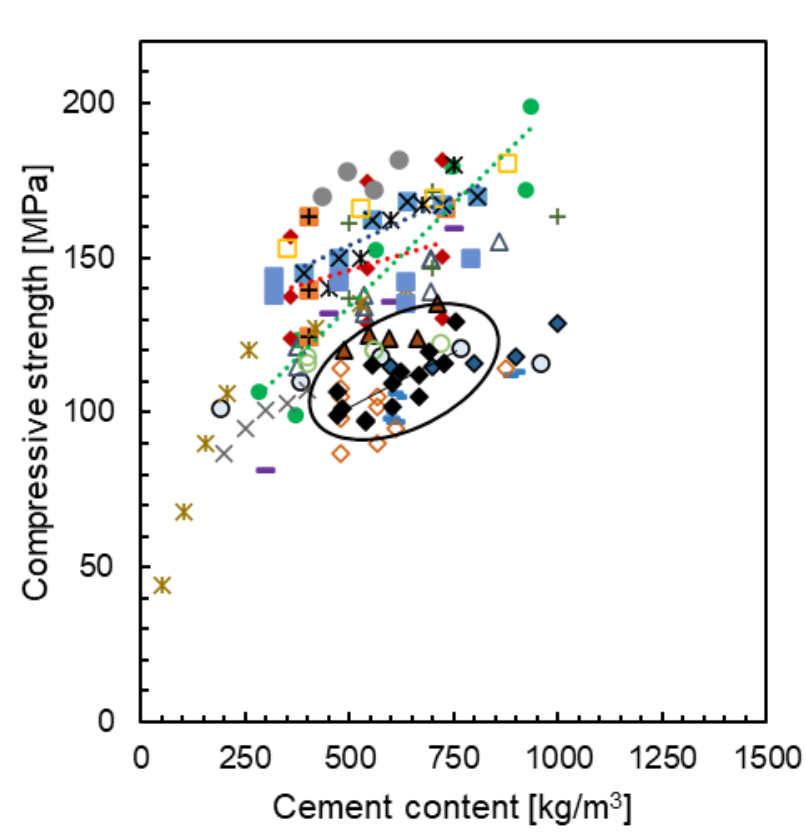

- Ahmed et al. (2021 a)

- Aldahdooh et al. (2013)

- Ganesh \& Murthy (2019)

$\triangle \quad$ Li et al. (2021)

- Mao et al.

$\Delta \quad$ Meng et al. (2017)

$\times \quad$ Qian et al (2020)

+ Randl et al. (2014)

* Shi et al. (2019)

x Soliman \& Tagnit-Hamou (2016)

$+\quad$ Tahwia et al. (2021)

- Hou et al. (2021)

$\square \quad$ Wang et al. (2021)

* Wang et al. (2018)

- Wu et al. (2017)

- Yang et al. (2020)

- Yu et al. (2015)

$\diamond \quad$ Zhang \& Zhao (2017)

- Zhang et al. (2019)

- This study - Lineær (Ahmed et al. (2021 a)) - Lineær (Aldahdooh et al. (2013) ) Lineær (Soliman \& Tagnit-Hamou (2016)) Lineær (This study)

(a) Compressive strength vs cement content

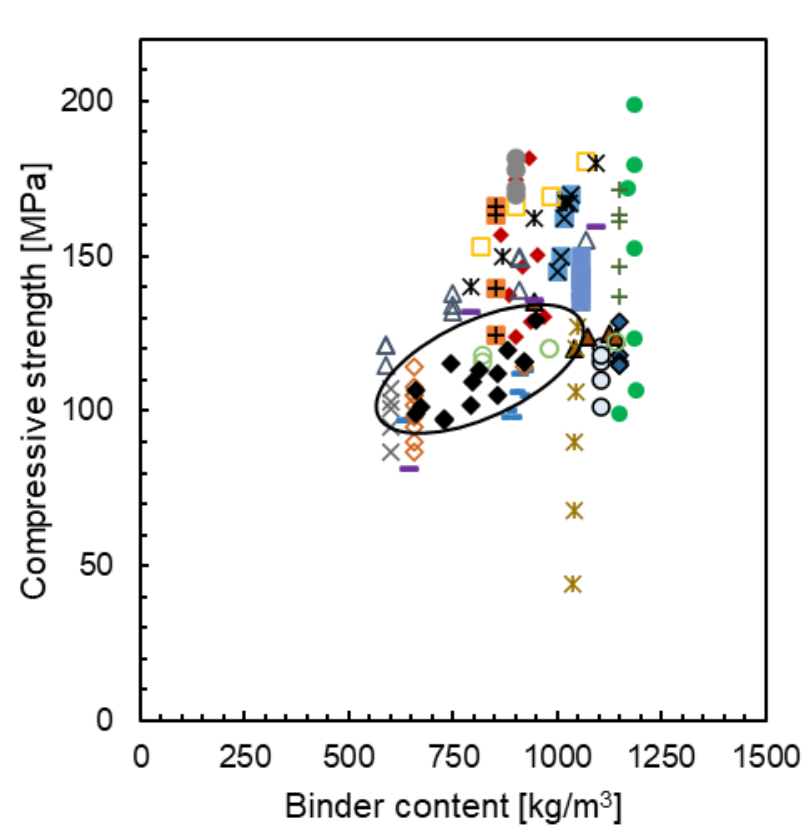

- Ahmed et al. (2021 a)

- Aldahdooh et al. (2013)

o Ganesh \& Murthy (2019)

$\triangle \mathrm{Li}$ et al. (2021)

$\checkmark$ Mao et al.

$\Delta$ Meng et al. (2017)

$\times$ Qian et al (2020)

* Randl et al. (2014)

* Shi et al. (2019)

x Soliman \& Tagnit-Hamou (2016)

+ Tahwia et al. (2021)

- Hou et al. (2021)

$\square$ Wang et al. (2021)

* Wang et al. (2018)

Wu et al. (2017)

- Yang et al. (2020)

-Yu et al. (2015)

$\diamond$ Zhang \& Zhao (2017)

- Zhang et al. (2019)

(b) Compressive strength $v$ s total binder content

Figure 10-Compressive strength vs cement/binder content, for specimens cured at $20^{\circ} \mathrm{C}$ in 28 days found in the literature compared to the results in this study (highlighted with a circle).

\section{3}

\section{Cement efficiency evaluation}

Figure 11 shows the calculated binder intensity $\left(b i_{c s}\right)$ and $\mathrm{CO}_{2}$ intensity $\left(c i_{c s}\right)$ of this study compared to the results from the literature. The method of calculating the two indices is explained in Section 2.3. The compressive strength results used in the calculations for both indices in the present investigation are those identified from testing according to ASTM C109/C109M. 


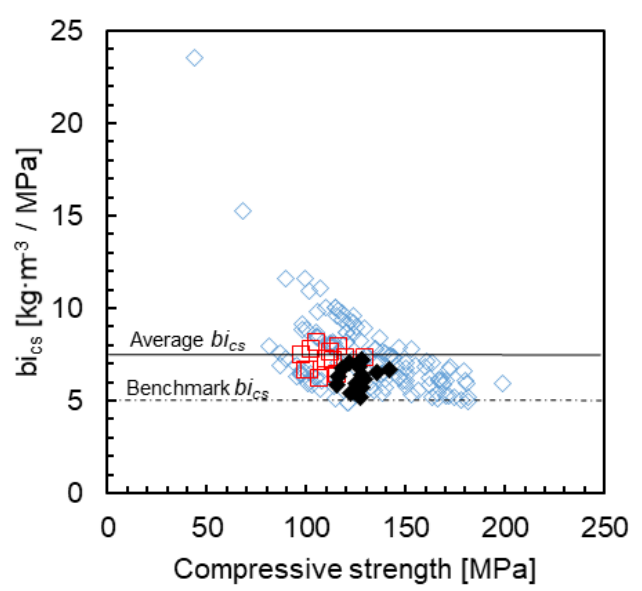

(a) binder intensity (bics) according to Eq. 2

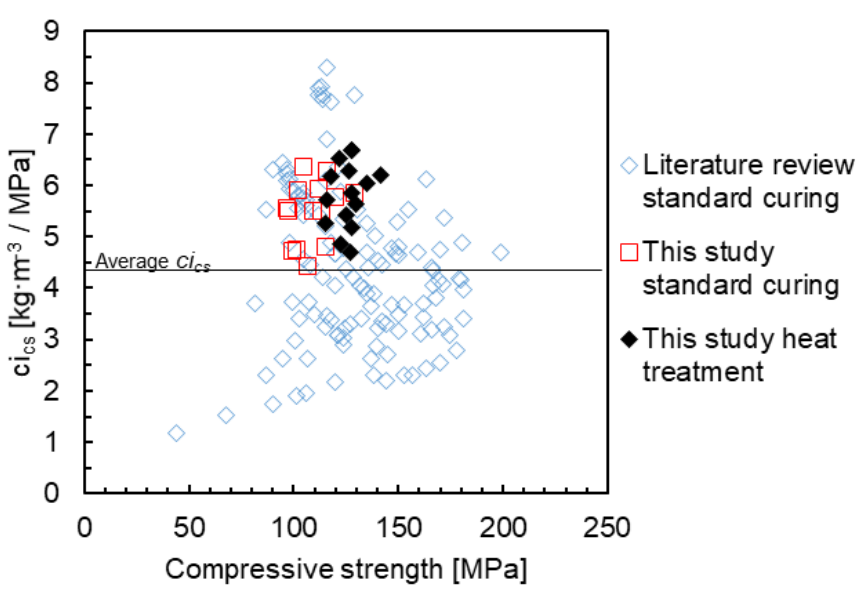

(b) $\mathrm{CO}_{2}$ intensity (ci $\left.i_{c s}\right)$ according to Eq. 3

Figure 11 - Compressive strength versus binder intensity/CO $\mathrm{O}_{2}$ intensity for results from this investigation, compared to results from other investigations identified in the literature review

The binder intensity (Figure $11 \mathrm{a}$ ) is intended for evaluating the cost perspective. In the present investigation, the index is calibrated to represent the amount of binder necessary to achieve $1 \mathrm{MPa}$ compressive strength. Hence, it is favourable to achieve as low binder intensity index $\left(b i_{\mathrm{cs}}\right)$ as possible. The solid line in the figure represents the average binder intensity (Average $b i_{c s}$ ) of the results in the included papers. Also, the line representing a purposed future international benchmark of $b i_{c s}$ for normal concrete according to [18], is depicted. This benchmark is $5.0 \mathrm{~kg}$ binder per $\mathrm{m}^{3}$ normal concrete per $1 \mathrm{MPa}$ compressive strength.

A general trend observable from all the data in Figure $11 \mathrm{a}$, is that the binder intensity decreases (favourable) as the compressive strength increases. The binder intensity $\left(\mathrm{kg} / \mathrm{m}^{3}\right.$ per MPa) of 981 collected international data presented by Damineli et al. (2010) [18] showed similar results. Damineli et al. also observed that for normal concrete with compressive strength above $60 \mathrm{MPa}$, the binder intensity was normally between 5 and $10 \mathrm{~kg} / \mathrm{m}^{3}$ per MPa. A minimum binder intensity was observed to reach a plateau of around $5.0 \mathrm{~kg} / \mathrm{m}^{3}$ per MPa. Results of the present literature review confirm that the tendency Damineli et al. found for high strength standard concrete is also a tendency for UHPC, which is illustrated in Figure 11 a.

The results for the UHPC material with cement substitution up to $40 \%$ found in the present investigation, performs correspondingly to the average of the results identified from the literature review. It is observable from Figure 11 that high temperature (heat treatment) curing seems favourable for the binder efficiency index. However, this index does not caretake the extra cost and other expenses related to this special curing regime. Increasing compressive strength through other measures like improving the particle packing and selecting high-quality aggregate would benefit the binder intensity index. The potential for both is demonstrated in this paper.

For most UHPC compositions identified in the present literature review, the binder intensity is not below the future benchmark $b i_{c s}\left(5.0 \mathrm{~kg} / \mathrm{m}^{3}\right.$ per MPa). For UHPC, a $b i_{c s}$ below 5 seems so far rarely to have been achieved, even for high replacement levels of cement. However, most investigations seem to focus on substituting cement with alternative binders, which would not benefit this index. The approach that is tested in the present investigation, reveals that cement can be successfully substituted with inert materials, which benefits the binder intensity index. This is 
visualised in Figure $11 \mathrm{a}$, where the highest markers for the present investigation represent the reference mixes, while the lower represents the stepwise cement substitution.

One method for further reducing the total binder content might be to reduce the high consumption of microsilica. The microsilica content is kept constant at 25 mass- $\%$ of the cement in the reference mix, through all replacement levels. A reduction of the microsilica would contribute to lower binder intensity if the compressive strength were maintained. However, the $D_{50}$ of the microsilica particles used in this investigation are on average $1 / 100$ of the cement particles. Thus, microsilica is anticipated to contribute significantly to the dense particle packing, and consequently to the compressive strength. Microsilica contributes more to the cost of UHPC than cement [7], and optimization would benefit the cost perspective, vaguely illustrated through the binder intensity index. Optimisation of the microsilica content of UHPC regarding the cost perspective remains to be investigated. An improvement of the binder intensity index might be to weigh the cost of each binding material.

Figure $11 \mathrm{~b}$ presents the estimated $\mathrm{CO}_{2}$ intensity of the included UHPC mixes identified in the literature review, compared to the results obtained in the present experimental investigation. The $\mathrm{CO}_{2}$ intensity index measures the $\mathrm{CO}_{2}$ emission per $1 \mathrm{MPa}$ compressive strength. Thus, again it is favourable to perform as low on the y-axis as possible (low $c i_{c s}$-index). The $\mathrm{CO}_{2}$ intensity of the collected international studies presented by Damineli et al. (2010) [18], claimed that the minimum $\mathrm{CO}_{2}$ intensity is $1.5 \mathrm{~kg} / \mathrm{m}^{3}$ per MPa for all ranges of concrete strength. The corresponding results from the investigations identified from the present literature review are illustrated in Figure $11 \mathrm{~b}$. With few exceptions, all results are far higher than what was claimed possible by Damineli et al. It seems that achieving both required strength values for UHPC (>120 MPa) and low $\mathrm{CO}_{2}$ intensity, is difficult.

The $c i_{c s}$ index achieved in the present investigation is above the average of the results from the literature review. But more important (since the overall score is manipulable by other measures like increasing the aggregate quality); the results show that the cement substitution reduces the Global Warming Potential (GWP) given by the $\mathrm{CO}_{2}$ intensity index. In the present investigation, the index was improved from around 7 (reference mix) to around 4.5 (40\% substitution level). The further reduction would be obtainable by substituting cement with high-quality SCMs since these materials are often industrial by-products (temporarily) considered to be without $\mathrm{CO}_{2}$ load. However, these kinds of measures would harm the cost efficiency, illustrated through the binder intensity index. It is, of course, beneficial to reduce the environmental impact of any material and activity at all levels. Consequently, measures like the one presented in this investigation prove it environmentally beneficial to substitute cement with inert materials. Thus, comparing material development efforts through e.g., the $\mathrm{CO}_{2}$ intensity index is meaningful. However, to understand the full environmental implications potentially related to the use of UHPC, it is necessary to compare full LCAs of alternative solutions. The main contribution from the use of UHPC is expected to stem from the possibility to construct more slender structures, consequently reducing the overall material consumption while also improving durability. This might be a powerful approach to reduce the $\mathrm{CO}_{2}$ emissions from the concrete industry, in line with Mehta's tool number $1[3]$.

\section{5.}

\section{CONCLUSION}

The following conclusions are suggested based on the discussion above: 
1) It was shown possible to substitute up to $40 \%$ of the cement in a typical locally produced UHPC mix, without significantly reducing the compressive strength or the flexural tensile strength. This is well corresponding with a variety of reports from other investigations on cement substitution, identified from a structured literature review which is also performed in the present work.

2) The measure that separates the present investigation from most other reported results, is that the cement was substituted with an inert material. Most investigations utilise materials with binding properties, often pozzolans. However, the effect on compressive strength from cement substitution found in this investigation is fully corresponding to those reported through the literature. Neither the flexural tensile strength was found to be reduced through the cement substitution. However, in practical use, UHPC is given flexural strength mainly through the inclusion of fibres. Whether the cement substitution would influence the flexural strength through manipulating the distribution or orientation of the fibres, has not been evaluated in this approach. Both the inert material used in the present investigation and most other materials used correspondingly in other investigations are industrial by-products considered to benefit circular economy and have low $\mathrm{CO}_{2}$ emissions.

3) Investigations on cement substitution always raise questions on related issues, like whether to keep $w / c$-ratio or $w / b$-ratio constant, and how to keep SP constant (constant SP content, or SP/C constant). Also, the effect of the curing regime at elevated temperature and the use of different standards are in question. All of these were evaluated through the present investigation and found not to have a considerable impact on the results.

4) Two indices reported in the literature for measuring respectively "binder intensity" (cost perspective) and " $\mathrm{CO}_{2}$ intensity" (Global Warming Potential perspective) have been identified and utilised to evaluate the present results towards those already reported in the research community. Substitution of cement by an inert material is found to improve significantly on the score of both indices and benchmark the performance towards corresponding results identified from the literature. The scores on both indexes are also found to be manipulable through other measures than cement (or binder) substitution.

5) Two commonly used indices are utilised in this paper; the binder intensity index $\left(b i_{c s}\right)$ and $\mathrm{CO}_{2}$ intensity index $\left(c i_{c s}\right)$. Shortcomings regarding both are discussed: i) The binder intensity index is intended for evaluating the cost perspective. Still, all binder materials are treated equally, disregarding that some are low-cost waste materials while others have cost several times that of Portland cement. An improvement of the binder efficiency index might be to weigh the different binder materials according to the cost level. ii) The $\mathrm{CO}_{2}$ intensity index includes only the emissions from cement. In the special case of UHPC, near $50 \%$ of the $\mathrm{CO}_{2}$ emissions stems from micro steel fibres. Thus, it is suggested that the $\mathrm{CO}_{2}$ intensity index is expanded to also comprise the $\mathrm{CO}_{2}$ emissions from the fibres.

The scores on both indices are found to be manipulable through other measures than cement (or binder) substitution. However, this is considered not to be a shortcoming, rather an opportunity that should be investigated through further research.

\section{ACKNOWLEDGEMENT}

The work presented in this paper is part of the ongoing project MEERC (More Efficient and Environmentally friendly Road Construction), partly funded by the Research Council of Norway (NFR) [project number 273700] and Sørlandets Kompetansefond [2016/33]. 


\section{REFERENCES}

1. Benhelal E, Zahedi G, Shamsaei E \& Bahadori A: "Global strategies and potentials to curb CO2 emissions in cement industry". Journal of Cleaner Production, Vol. 51, 2013, pp. 142-161.

2. $\quad$ Larsen I L, Terjesen O, Thorstensen R T \& Kanstad T: "Use of Concrete for Road Infrastructure: A SWOT Analysis Related to the three Catchwords Sustainability, Industrialisation and Digitalisation". Nordic Concrete Research, Vol. 60, No. 1, 2019, pp. 31-50.

3. Mehta P K: "Global concrete industry sustainability". Concrete international, Vol. 31, No. 2, 2009, pp. 45-48.

4. Graybeal B, Brühwiler E, Kim B-S, Toutlemonde F, Voo Y L \& Zaghi A: "International perspective on UHPC in bridge engineering". Journal of Bridge Engineering, Vol. 25, No. 11, 2020, p. 04020094.

5. Russell H G, Graybeal B A \& Russell H G: "Ultra-high performance concrete: A stateof-the-art report for the bridge community". Federal Highway Administration., United States, Publication no. FHWA-HRT-13-060, 2013.

6. $\quad$ Lande I \& Thorstensen R T: "Locally Produced UHPC: The Influence of Type and Content of Steel Fibres". Nordic Concrete Research, Vol. 64, No. 1, 2021, pp. 31-52.

7. Stengel T \& Schieß1 P: "22 - Life cycle assessment (LCA) of ultra high performance concrete (UHPC) structures". "Eco-efficient Construction and Building Materials", F Pacheco-TorgalL F CabezaJ Labrincha, \& A de Magalhães, Eds., Woodhead Publishing, 2014, pp. 528-564.

8. Graybeal B A: "Development of Non-Proprietary Ultra-High Performance Concrete for Use in the Highway Bridge Sector: TechBrief". United States. Federal Highway Administration, 2013.

9. $\quad$ Yu R, Spiesz P \& Brouwers H J H: "Mix design and properties assessment of Ultra-High Performance Fibre Reinforced Concrete (UHPFRC)". Cement and Concrete Research, Vol. 56, 2014, pp. 29-39.

10. Scrivener K L, John V M \& Gartner E M: "Eco-efficient cements: Potential economically viable solutions for a low-CO2 cement-based materials industry". Cement and Concrete Research, Vol. 114, 2018, pp. 2-26.

11. Moher D, Liberati A, Tetzlaff J, Altman D G \& The P G: "Preferred Reporting Items for Systematic Reviews and Meta-Analyses: The PRISMA Statement". PLOS Medicine, Vol. 6, No. 7, 2009, p. e1000097.

12. Ouzzani M, Hammady H, Fedorowicz Z \& Elmagarmid A: "Rayyan - a web and mobile app for systematic reviews". Systematic Reviews, Vol. 5, No. 1, 2016, p. 210.

13. Funk J E \& Dinger D R: "Derivation of the Dinger-Funk Particle Size Distribution Equation". "Predictive Process Control of Crowded Particulate Suspensions: Applied to Ceramic Manufacturing", Springer US, Boston, MA, 1994, pp. 75-83.

14. Andreasen A H M \& Andersen J: "On the relationship between grain gradation and space in products made from loose grains (with some experiments)". ("Ueber die Beziehung zwischen Kornabstufung und Zwischenraum in Produkten aus losen Körnern (mit einigen Experimenten")". Kolloid-Zeitschrift, Vol. 50, No. 3, 1930 pp. 217-228. (In German).

15. Graybeal B A: "Material property characterization of ultra-high performance concrete". Federal Highway Administration, United States, No.: FHWA-HRT-06-103, 2006, p. 186. 
16. Graybeal B \& Davis M: "Cylinder or cube: strength testing of 80 to $200 \mathrm{MPa}$ (11.6 to 29 ksi) ultra-high-performance fiber-reinforced concrete". ACI Materials Journal, Vol. 105, No. 6, 2008, p. 603.

17. Riedel P, Leutbecher T, Piotrowski S \& Heese C: "Ratios of compressive strengths of ultra-high-performance concrete specimens of different shapes and sizes". ACI Materials Journal, Vol. 116, No. 6, 2019, pp. 139-149.

18. Damineli B L, Kemeid F M, Aguiar P S \& John V M: "Measuring the eco-efficiency of cement use". Cement and Concrete Composites, Vol. 32, No. 8, 2010, pp. 555-562.

19. Flower D J M \& Sanjayan J G: "Green house gas emissions due to concrete manufacture". The International Journal of Life Cycle Assessment, Vol. 12, No. 5, 2007, p. 282.

20. Shi Y, Long G, Ma C, Xie Y \& He J: "Design and preparation of ultra-high performance concrete with low environmental impact". Journal of Cleaner Production, Vol. 214, 2019, pp. 633-643.

21. Abdulkareem O M, Fraj A B, Bouasker M, Khouchaf L \& Khelidj A: "Microstructural investigation of slag-blended UHPC: The effects of slag content and chemical/thermal activation". Construction and Building Materials, Vol. 292, 2021,

22. Aghdasi P \& Ostertag C P: "Green ultra-high performance fiber-reinforced concrete (GUHP-FRC)". Construction and Building Materials, Vol. 190, 2018, pp. 246-254.

23. Ahmed T, Elchalakani M, Karrech A, Dong M, Mohamed Ali M S \& Yang H: "ECOUHPC with High-Volume Class-F Fly Ash: New Insight into Mechanical and Durability Properties". Journal of Materials in Civil Engineering, Vol. 33, No. 7, 2021,

24. Ahmed T, Elchalakani M, Karrech A, Mohamed Ali M S \& Guo L: "Development of ECO-UHPC with very-low-C3A cement and ground granulated blast-furnace slag". Construction and Building Materials, Vol. 284, 2021, p. 122787.

25. Aldahdooh M A A, Muhamad Bunnori N \& Megat Johari M A: "Development of green ultra-high performance fiber reinforced concrete containing ultrafine palm oil fuel ash". Construction and Building Materials, Vol. 48, 2013, pp. 379-389.

26. Alsalman A, Dang C N, Martí-Vargas J R \& Micah Hale W: "Mixture-proportioning of economical UHPC mixtures". Journal of Building Engineering, Vol. 27, 2020, p. 100970.

27. Ganesh P \& Murthy A R: "Tensile behaviour and durability aspects of sustainable ultrahigh performance concrete incorporated with GGBS as cementitious material". Construction and Building Materials, Vol. 197, 2019, pp. 667-680.

28. Hou D, Wu D, Wang X, Gao S, Yu R, Li M, Wang P \& Wang Y: "Sustainable use of red mud in ultra-high performance concrete (UHPC): Design and performance evaluation". Cement and Concrete Composites, Vol. 115, 2021, p. 103862.

29. Huang W, Kazemi-Kamyab H, Sun W \& Scrivener K: "Effect of cement substitution by limestone on the hydration and microstructural development of ultra-high performance concrete (UHPC)". Cement and Concrete Composites, Vol. 77, 2017, pp. 86-101.

30. Jing R, Liu Y \& Yan P: "Uncovering the effect of fly ash cenospheres on the macroscopic properties and microstructure of ultra high-performance concrete (UHPC)". Construction and Building Materials, Vol. 286, 2021,

31. Li P P, Brouwers H J H, Chen W \& Yu Q: "Optimization and characterization of highvolume limestone powder in sustainable ultra-high performance concrete". Construction and Building Materials, Vol. 242, 2020,

32. Li P P, Cao Y Y Y, Brouwers H J H, Chen W \& Yu Q L: "Development and properties evaluation of sustainable ultra-high performance pastes with quaternary blends". Journal of Cleaner Production, Vol. 240, 2019, 
33. Li Y, Zeng X, Zhou J, Shi Y, Umar H A, Long G \& Xie Y: "Development of an ecofriendly ultra-high performance concrete based on waste basalt powder for SichuanTibet Railway". Journal of Cleaner Production, Vol. 312, 2021,

34. Ling G, Shui Z, Gao X, Sun T, Yu R \& Li X: "Utilizing iron ore tailing as cementitious material for eco-friendly design of ultra-high performance concrete (Uhpc)". Materials, Vol. 14, No. 8, 2021,

35. Liu G, Schollbach K, Li P \& Brouwers H J H: "Valorization of converter steel slag into eco-friendly ultra-high performance concrete by ambient $\mathrm{CO} 2$ pre-treatment". Construction and Building Materials, Vol. 280, 2021,

36. Liu Y, Wei Y \& Guo W: "Effect of Filler Type, Fineness, and Shape on the Properties of Nonfibrous UHPC Matrix". Journal of Materials in Civil Engineering, Vol. 33, No. 5, 2021, p. 04021084.

37. Mao X, Qu W \& Zhu P: "Mixture Optimization of Green Reactive Powder Concrete with Recycled Powder". Journal of Materials in Civil Engineering, Vol. 31, No. 5, 2019, p. 04019033.

38. Meng W, Valipour M \& Khayat K H: "Optimization and performance of cost-effective ultra-high performance concrete". Materials and Structures, Vol. 50, No. 1, 2016, p. 29.

39. Qian D, Yu R, Shui Z, Sun Y, Jiang C, Zhou F, Ding M, Tong X \& He Y: "A novel development of green ultra-high performance concrete (UHPC) based on appropriate application of recycled cementitious material". Journal of Cleaner Production, Vol. 261, 2020 ,

40. Randl N, Steiner T, Ofner S, Baumgartner E \& Mészöly T: "Development of UHPC mixtures from an ecological point of view". Construction and Building Materials, Vol. 67, 2014, pp. 373-378.

41. Soliman N A \& Tagnit-Hamou A: "Development of ultra-high-performance concrete using glass powder - Towards ecofriendly concrete". Construction and Building Materials, Vol. 125, 2016, pp. 600-612.

42. Tahwia A M, Elgendy G M \& Amin M: "Durability and microstructure of eco-efficient ultra-high-performance concrete". Construction and Building Materials, Vol. 303, 2021,

43. Wang X, Wu D, Geng Q, Hou D, Wang M, Li L, Wang P, Chen D \& Sun Z: "Characterization of sustainable ultra-high performance concrete (UHPC) including expanded perlite". Construction and Building Materials, Vol. 303, 2021,

44. Wang X, Yu R, Shui Z, Zhao Z, Song Q, Yang B \& Fan D: "Development of a novel cleaner construction product: Ultra-high performance concrete incorporating lead-zinc tailings". Journal of Cleaner Production, Vol. 196, 2018, pp. 172-182.

45. Wu Z, Shi C \& He W: "Comparative study on flexural properties of ultra-high performance concrete with supplementary cementitious materials under different curing regimes". Construction and Building Materials, Vol. 136, 2017, pp. 307-313.

46. Xu K, Huang W, Zhang L, Fu S, Chen M, Ding S \& Han B: "Mechanical properties of low-carbon ultrahigh-performance concrete with ceramic tile waste powder". Construction and Building Materials, Vol. 287, 2021,

47. Yang R, Yu R, Shui Z, Gao X, Han J, Lin G, Qian D, Liu Z \& He Y: "Environmental and economical friendly ultra-high performance-concrete incorporating appropriate quarry-stone powders". Journal of Cleaner Production, Vol. 260, 2020,

48. Yu R, Song Q, Wang X, Zhang Z, Shui Z \& Brouwers H J H: "Sustainable development of Ultra-High Performance Fibre Reinforced Concrete (UHPFRC): Towards to an optimized concrete matrix and efficient fibre application". Journal of Cleaner Production, Vol. 162, 2017, pp. 220-233. 
49. Yu R, Spiesz P \& Brouwers H J H: "Development of an eco-friendly Ultra-High Performance Concrete (UHPC) with efficient cement and mineral admixtures uses". Cement and Concrete Composites, Vol. 55, 2015, pp. 383-394.

50. Zhang J \& Zhao Y: "The mechanical properties and microstructure of ultra-highperformance concrete containing various supplementary cementitious materials". Journal of Sustainable Cement-Based Materials, Vol. 6, No. 4, 2017, pp. 254-266.

51. Zhang X, Zhao S, Liu Z \& Wang F: "Utilization of steel slag in ultra-high performance concrete with enhanced eco-friendliness". Construction and Building Materials, Vol. 214, 2019, pp. 28-36.

52. Zhu P, Mao X, Qu W, Li Z \& Ma Z J: "Investigation of using recycled powder from waste of clay bricks and cement solids in reactive powder concrete". Construction and Building Materials, Vol. 113, 2016, pp. 246-254.

53. Thorstensen R T \& Fidjestol P: "Inconsistencies in the pozzolanic strength activity index (SAI) for silica fume according to EN and ASTM". Materials and Structures, Vol. 48, No. 12, 2015, pp. 3979-3990. 